\title{
Circulation patterns in the lower Arctic Ocean derived from geochemical data
}

\author{
Motoyoshi Ikeda $^{1}$ (I) Shinichi S. Tanaka ${ }^{1,2} \cdot$ Yutaka W. Watanabe $^{1}$
}

Received: 10 August 2017 / Revised: 26 March 2018 / Accepted: 30 March 2018 / Published online: 17 April 2018

(c) The Author(s) 2018

\begin{abstract}
Climatological water-mass structures were identified in the Arctic Ocean using the geochemical dataset in the Hydrochemical Atlas of the Arctic Ocean (HAAC) as well as data on a geochemically conserved parameter, $\mathrm{PO}_{4}{ }^{*}$, based on phosphate and dissolved oxygen. In the upper ocean above a depth of $500 \mathrm{~m}$, the HAAC was found to reliably depict the boundary between Pacific-Origin Water (P-Water) and Atlantic-Origin Water (A-Water), which is aligned $135^{\circ} \mathrm{E}-45^{\circ} \mathrm{W}$ near the surface but rotates counterclockwise with depth. Thus, the Arctic and Atlantic oceans exchange high-silicate P-Water and low-silicate A-Water. The $\mathrm{PO}_{4}{ }^{*}$ field in the lower ocean below a depth of $1500 \mathrm{~m}$ was analyzed statistically, and the results indicated that the Eurasian Basin receives low- $\mathrm{PO}_{4}{ }^{*}$ Nordic Seas Deep Water, which flows along the bottom from the Greenland Sea. The routes from the upper ocean to the lower ocean were determined. Only the southern portion of the Canada Basin, which receives water from the Chukchi and Beaufort Seas, has high $\mathrm{PO}_{4}{ }^{*}$ levels; the rest of the Amerasian Basin receives low- $\mathrm{PO}_{4}$ * water from the Laptev Sea and/or the Barents Sea. The Eurasian Basin receives moderate levels of $\mathrm{PO}_{4}{ }^{*}$ from the Fram Strait and from the intermediate layer. The intermediate-layer water gradually travels up from the lower ocean and returns to the Atlantic, entraining the subsurface portion. It is likely that high $-\mathrm{PO}_{4}{ }^{*}$ water occasionally flows down from the upper ocean along Greenland, making the Eurasian Basin heterogeneous.
\end{abstract}

Keywords Arctic Ocean · Ocean circulation $\cdot$ Arctic-Atlantic water exchange $\cdot$ Geochemical data $\cdot$ Geochemical conservative tracer

\section{Introduction}

It is rather difficult to observe the circulation of the Arctic Ocean, as sea ice covers the majority of the ocean for $>9$ months of the year. Since it is therefore extremely difficult to directly measure velocities in the lower ocean (the bathypelagic layer), one way to explore the circulation in this layer is to analyze geochemical data. However, before performing such an analysis, we need to verify the accuracy of the geochemical data for the lower ocean by comparing the geochemical data for the upper ocean with the known circulation patterns in the upper ocean. Provided the circulation

Motoyoshi Ikeda

mikeda@ees.hokudai.ac.jp

1 Graduate School of Environmental Earth Science, Hokkaido University, Kita 10 Nishi 5, Kita-ku, Sapporo 060-0810, Japan

2 Earthquake Research Institute, The University of Tokyo, 1-1-1 Yayoi, Bunkyo-ku, Tokyo 113-0032, Japan patterns derived from the geochemical data for the upper ocean are a good match for the actual circulation patterns in the upper ocean, we can be reasonably sure that the circulation patterns derived from the geochemical data for the lower ocean will also be relatively accurate.

The circulation patterns in the Arctic Ocean, as derived in previous studies, are shown schematically in Fig. 1. Some features of this circulation have been confirmed, although much of it is still to be confirmed. In the upper ocean above a depth of $500 \mathrm{~m}$ (Fig. 1a), the climatological circulation is primarily driven by the buoyancy flux due to low-salinity water from the Pacific and river discharges (Aagaard and Carmack 1989). The surface layer (the top $200 \mathrm{~m}$ ) includes the Transpolar Drift Stream which transports seawater to the North Atlantic (Spall 2013). Salinity and temperature distributions derived from climatological data are shown in Fig. 2a, d, and represent basic sources of information on density-related circulation in the Arctic Ocean. The salinity contrast (about 1.5) dominates over the temperature contrast $\left(5^{\circ} \mathrm{C}\right)$ for the density structures in the Arctic Ocean. 
(a)

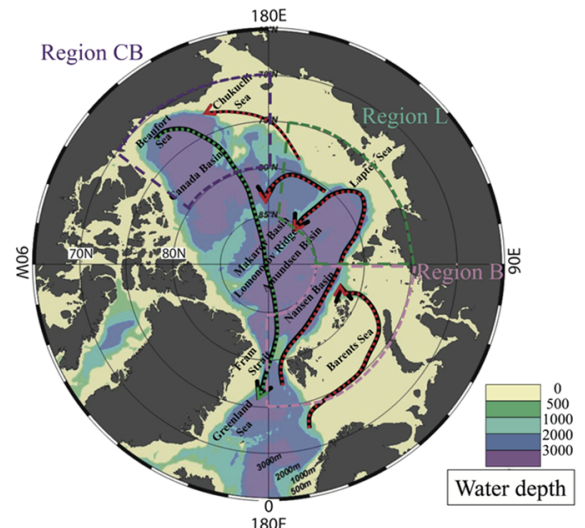

(b)

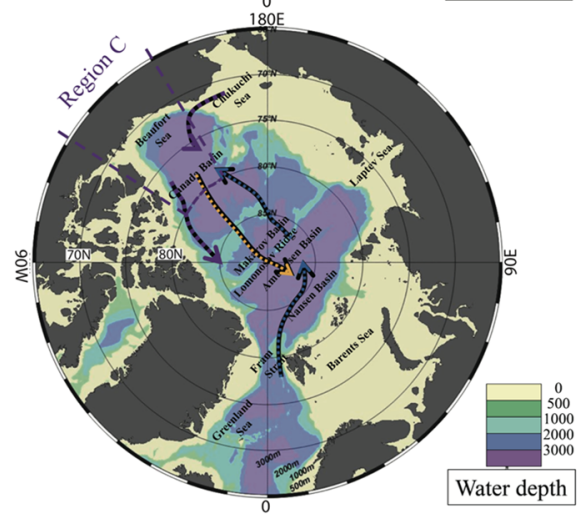

(c)

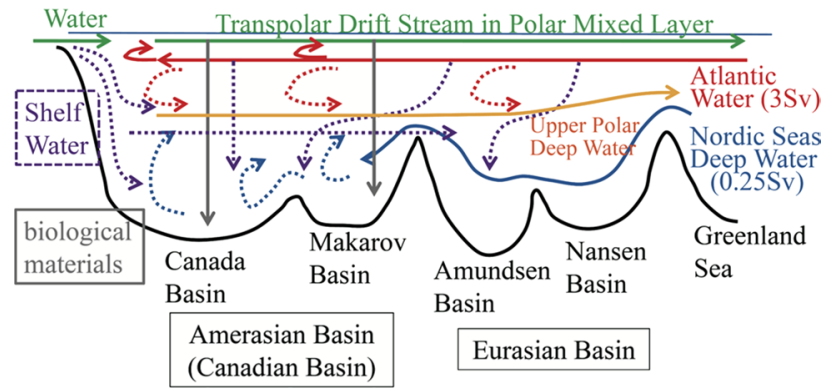

Fig. 1a-c Schematic of the circulation in the Arctic Ocean. a The upper ocean. b The lower ocean plus the intermediate layer. The Amerasian Basin includes the Canada Basin and the Makarov Basin, and the Eurasian Basin includes the Amundsen Basin and the Nansen Basin. The regions specified in Table 1 are a region CB at $200 \mathrm{~m}$ depth and at $70^{\circ} \mathrm{N}-80^{\circ} \mathrm{N}, 130^{\circ} \mathrm{W}-180^{\circ}$, region $\mathrm{L}$ at $200 \mathrm{~m}$ depth and at $75^{\circ} \mathrm{N}-85^{\circ} \mathrm{N}, 90^{\circ} \mathrm{E}-170^{\circ} \mathrm{E}$, and region $\mathrm{B}$ at $200-500 \mathrm{~m}$ depth and at $75^{\circ} \mathrm{N}-85^{\circ} \mathrm{N}, 0^{\circ} \mathrm{E}-90^{\circ} \mathrm{E}$, as well as b region $\mathrm{C}$ below $2000 \mathrm{~m}$ depth and at $150^{\circ} \mathrm{W}-120^{\circ} \mathrm{W}$, south of $80^{\circ} \mathrm{N}$. Depth contours are shown for $500,1000,2000$, and $3000 \mathrm{~m}$. c Schematic of the circulation patterns along the section between the Bering Strait and the Fram Strait. The five solid lines indicate water circulation patterns that have been confirmed in previous studies: the Pacific Water inflow, Transpolar Drift Stream, Atlantic Water inflow, Upper Polar Deep Water flow and Nordic Seas Deep Water inflow. The gray lines indicate the flux of biological material. Three dotted lines indicate water fluxes that were previously proposed and were investigated in the present study: the shelf water sinking flow (purple), entrainment from the subsurface layer of Atlantic Water into the intermediate layer (red), and entrainment from the lower ocean into the intermediate layer (blue). These flow patterns are taken from Aagaard et al. (1985), Aagaard and Carmack (1989), Jones et al. (1995), Timmermans et al. (2005), Arthun et al. (2011), Rudels (2012), and Spall (2013)
It should be noted that wind forcing induces seasonal and interannual fluctuations (e.g., Haller 2014; Ikeda 2014; Yoshizawa et al. 2015; Mizobata et al. 2016).

The Atlantic Water flows toward the Canada Basin in the subsurface layer at depths of around 200-500 $\mathrm{m}$ (Spall 2013), with a volume flux of about $3-4 \mathrm{~Sv}\left(1 \mathrm{~Sv}=10^{6} \mathrm{~m}^{3} \mathrm{~s}^{-1}\right)$. It is fed by a few branches from the Greenland Sea through the Fram Strait and the Barents Sea (Aksenov et al. 2011; Arthun et al. 2011; Pnyushkov et al. 2013, 2015). A belt of warm water is visible at $200 \mathrm{~m}$ depth along the shelf break of the Barents-Kara-Laptev seas, which provides proof of the Atlantic Water inflow. A thorough review of the circulation in the upper ocean can be found in Rudels (2012). It has been confirmed that the Pacific Water is less saline than the Atlantic Water. As for geochemical properties, the Pacific Water contains more silicate and less dissolved oxygen below the surface mixed layer, in clear contrast to the Atlantic Water (Levitus 2002), so we would expect to be able to use geochemical tracers to discern the circulation patterns in the Arctic Ocean.

In the lower ocean below $1500 \mathrm{~m}$ depth (Fig. 1b, c), the circulation patterns are rather complicated and show only weak variations in the properties of the water. Except for observations performed by the former Soviet Union, the first large-scale marine observation, ARKTIS IV, was carried out in September 1987 (e.g., Anderson et al. 1989) in the Nansen Basin. In addition to exploring the upper ocean, ARKTIS IV highlighted the presence of gentle vertical profiles below $1000 \mathrm{~m}$, with the temperature dropping by $0.5^{\circ} \mathrm{C}$ and the salinity by 0.02 at the bottom. Chlorofluorocarbons (CFCs), which are transient tracers, were detected at around $3200 \mathrm{~m}$ depth, suggesting that deep water was formed and flowed into the basin (Smethie et al. 1988). The observational project Oden 91 took place in the Nansen Basin and Amundsen Basin in 1991. It covered a large area including the North Pole and found that the lower ocean water in the Amerasian Basin was supplied by inflow from the Eurasian Basin and by downward flow from the shelf area (e.g., Jones et al. 1995). It should be noted that the Amerasian Basin is also called the Canada Basin.

While there is no geographical barrier between the Amerasian Basin and Eurasian Basin above the lower ocean, the horizontal distributions of oceanographic components show significant fronts in the upper ocean between the basins. This indicates that the bottom topography even has a significant impact on the ocean circulation patterns in the upper ocean, which are also influenced by wind stress curl (Spall 2013). The deep water masses in the Eurasian Basin are affected by the inflow of the Atlantic Water via the Fram Strait, based on the distribution of CFCs (Smethie et al. 1988). In addition, part of the bottom water is attributable to sinking high-density water from the adjacent continental shelves (Aagaard et al. 1985; Arthun et al. 2011). The deep water 
in the Amerasian Basin originates partly from density flows from the continental slope triggered by brine rejections (Jones et al. 1995; Rudels 2012). Following Oden 91, Jones (2001) suggested that water flows from the Eurasian Basin to the Amerasian Basin below about $1700 \mathrm{~m}$ depth in the lower ocean. Timmermans et al. (2005) estimated that the over-sill flow transport on the Lomonosov Ridge from the Amundsen Basin to the Makarov Basin was about $0.25 \mathrm{~Sv}$, based on density structures around the sill. Thus, the volume transport in the lower ocean is around $10 \%$ or less of that in the upper ocean. As a result of these flow patterns, the lower ocean in the Amerasian Basin is $0.4{ }^{\circ} \mathrm{C}$ warmer and 0.01 more saline than the lower ocean in the Eurasian Basin.

Geochemical parameters are modified by chemical reactions and biological processes. Hence, these processes must be understood and analyzed appropriately so that water masses can be tracked. Anderson et al. (1994) discussed the characteristics of each water mass based on an observational dataset. The horizontal distributions of the salinity, nutrients, and total alkalinity in the surface layer are fundamentally determined by the location of the Transpolar Drift Stream and controlled by the mixing process associated with mesoscale eddies between the Pacific Water on the North Pole side and the Atlantic Water on the Barents Sea side. The distribution of Atlantic Water along the Siberian shelves can be traced via geochemical components such as tritium and iodine, although the results are influenced to some degree by wind forcing (Smethie et al. 2000; Karcher et al. 2012). On the other hand, the vertical gradient of silicate is also affected by biological activity near the shelves (Wilson and Wallace 1990; Tremblay 2008). The upper halocline below the surface mixed layer primarily matches with the nutrient level maxima. High nutrient levels were observed to occur in the surface layer in the Canada Basin and to be transported to the halocline.

Since the observation stations used in those expeditions were focused on the Eurasian Basin, the water properties of the Amerasian Basin have not been explored sufficiently. One useful resource for clarifying the water properties of the Arctic Ocean is the Hydrochemical Atlas of the Arctic Ocean (HAAC), which contains much of the oceanic chemical data collected at drifting stations (North Pole stations) in the Arctic Basin (Arctic and Antarctic Research Institute 2001) from the 1940s until fairly recently. The observation program and dataset were described by Frolov et al. (2005), who provided useful information on the lower ocean in particular. A large amount of observational data is needed to clarify the spatiotemporal distributions of chemical components in the Arctic Ocean. A couple of studies have used HAAC data along with numerical models. Ikeda et al. (2005) used silicate data to derive the vertical motion of the upper halocline on a decadal timescale in response to the Northern Annular Mode (NAM), which is the first empirical orthogonal component, and found a steep positive gradient at around $300 \mathrm{~m}$ depth. Ikeda (2014) examined horizontal movement in the Arctic Ocean and found that the dominant atmospheric mode shifted from the NAM to the Arctic Dipole Mode (ADM), the second empirical orthogonal component, around the year 1990. In that work, silicate and dissolved oxygen fields highlighted the movement of the Transpolar Drift Stream due to the NAM and an oscillation of Pacific Water between the Atlantic and Pacific sides due to the ADM.

This paper summarizes work done by the authors to clarify the properties of the waters and track their routes throughout the entire Arctic Ocean using the HAAC. We have structured the paper as follows. In Sect. 2, the HAAC dataset is described, and the basic principles of geochemical reactions are introduced. A geochemical tracer which is conserved along a moving water mass is selected. In Sect. 3, the distribution of the tracer in the upper ocean is statistically analyzed and compared with the circulation patterns and water mass distributions derived in previous studies. The HAAC dataset is compared with information collected in other studies in order to maximize its reliability, thus allowing it to be used to examine mean field changes over half a century.

The lower ocean is then examined in Sect. 4, so that the experimentally inferred and more clearly proved circulation, such as the over-sill flow from the Amundsen Basin to the Makarov Basin (Timmermans et al. 2005). Analyses of the HAAC data are shown to be able to identify the hypothetical circulation patterns and geochemical processes, with a focus on the sources of water in the Amerasian Basin. In particular, the main aim of this work was to distinguish the flow from the Pacific side (the Beaufort Sea and the Chukchi Sea) and the flow from the Atlantic side (the Laptev Sea and the Barents Sea) into the lower ocean of the Amerasian Basin. The routes of the water sources are compared with the routes suggested by Aagaard et al. (1985), Arthun et al. (2011), Aksenov et al. (2011), Rudels (2012), Karcher et al. (2012), and Pnyushkov et al. (2015). The analyses highlight a possible candidate for the downward motion to the Eurasian Basin, cyclonic circulation along the shelf break towards the Greenland side. The results are summarized and discussed in Sect. 5, as are possible future research directions in relation to identifying water masses and their origins throughout the Arctic Ocean. 
Salinity
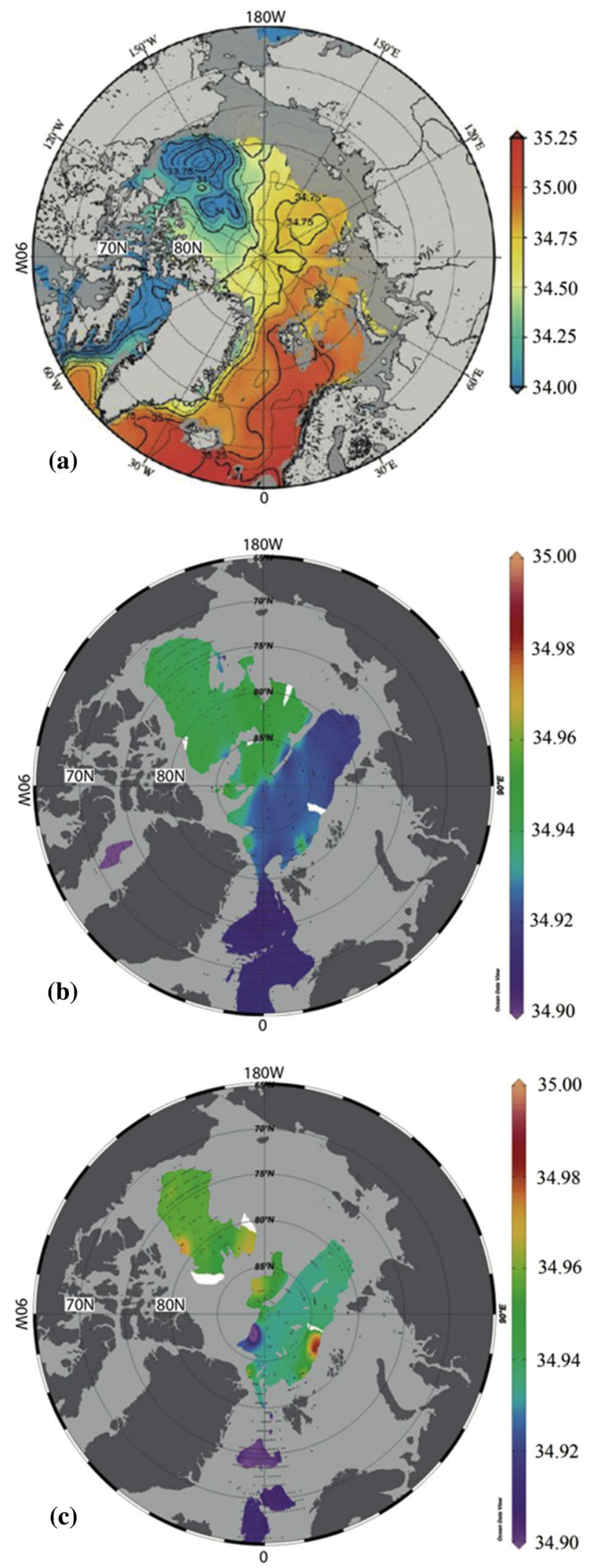

Temperature
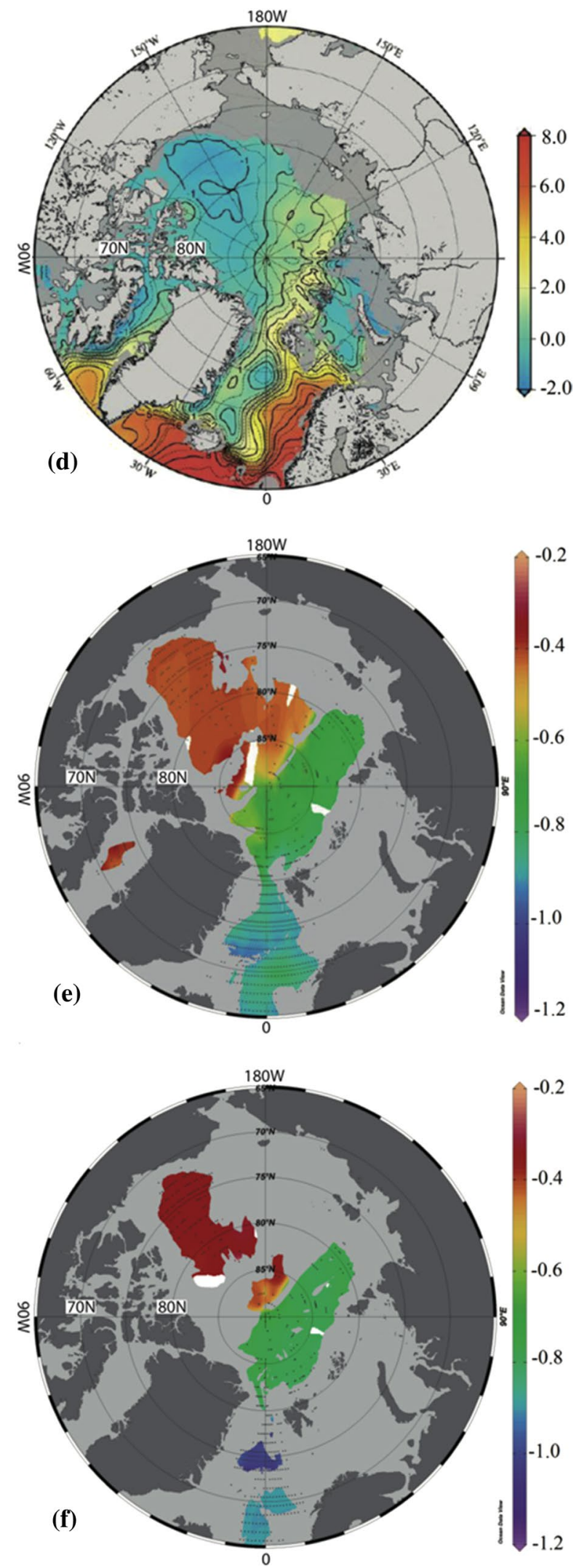
४Fig. 2a-f Annual mean salinity at a $200 \mathrm{~m}$ depth, b $2000 \mathrm{~m}$ depth, and c $3000 \mathrm{~m}$ depth, and annual mean temperature at $\mathbf{d} 200 \mathrm{~m}$ depth, e $2000 \mathrm{~m}$ depth, and f $3000 \mathrm{~m}$ depth. Data were obtained from the NOAA's National Centers for Environmental Information, https:// www.nodc.noaa.gov/cgi-bin/OC5/NPclimatology/, except for the values for $200 \mathrm{~m}$ depth obtained at a resolution of $0.25^{\circ}$, which were obtained directly at the site

\section{Dataset and geochemical analysis methods}

\subsection{Dataset}

The Hydrochemical Atlas of the Arctic Ocean (HAAC) is a collection of oceanographic survey data obtained mainly by the Soviet Federation and Russia between the 1940s and 2000. The chemical parameters included in the atlas are dissolved oxygen (DO, 111127 observations), silicate ( $\mathrm{Si}$, 102750 observations), $\mathrm{pH}$ (74730 observations), phosphate ( $\mathrm{PO}_{4}, 43132$ observations), nitrate (26465 observations), alkalinity (19442 observations), and nitrite (16201 observations). Figure 3 shows the spatiotemporal distribution for the observations. A large amount of $\mathrm{Si}, \mathrm{DO}$, and $\mathrm{PO}_{4}$ data for the Amerasian Basin and the Eurasian Basin was collected during the 1970s, especially during winter (Fig. 3c). The analytical errors in the $\mathrm{Si}, \mathrm{DO}$, and $\mathrm{PO}_{4}$ data due to the particular measuring devices used were about $6,3.4$, and $5 \%$, respectively, which are sufficiently low to allow differences in water properties between the Amerasian Basin and Eurasian Basin to be distinguished.

In addition to the chemical data, data on various other parameters such as cloud cover were collected using ships and drifting stations (North Pole stations), although data on physical oceanographic properties are not included in the HAAC. The geochemical parameters represent both biogeochemical and physical processes that occur in the ocean. We first focus on the physical processes by isolating the biogeochemical processes with a view to using geochemical parameters as tracers. The geochemical data are distributed throughout the Arctic Ocean with high spatial and temporal heterogeneity. We focus on mean states in the present analysis.

\subsection{Geochemical analysis methods}

We wish to trace water masses in this study. For example, Wilson and Wallace (1990) tried to identify the source region for the halocline water by distinguishing the Pacific Water from a water mass that is significantly influenced by the continental shelf. In the present study, in order to trace water masses using biogeochemical processes, we need to identify chemical components that are conserved during such processes. There is the possibility that different water masses derive from the same source, even when those water masses differ in their DO and nutrient levels. Let us consider the case where one water mass receives organic matter that is subsequently remineralized, consuming DO. We can estimate $\mathrm{PO}_{4}{ }^{*}$ by noting that remineralization of organic matter in the water column causes the content of phosphate to increase as the level of dissolved oxygen decreases according to the remineralization stoichiometry of $1 \mathrm{P}$ to $-175 \mathrm{O}_{2}$ (Broecker 1991) as follows:

$\mathrm{PO}_{4}{ }^{*}=\mathrm{PO}_{4}+\mathrm{DO} / 175-1.95$.

If the $\mathrm{PO}_{4}{ }^{*}$ values of two water masses are very similar, there is a high possibility that the water masses have a common source. This tracer $\left(\mathrm{PO}_{4}{ }^{*}\right)$ has been used to probe the hydrologic cycle in the upper ocean (Ekwurzel et al. 2001; Bauch et al. 2011). It is worth mentioning at this point that a diatom has an opal shell that contains silica $\left(\mathrm{SiO}_{2}\right)$, and oxygen is neither produced nor consumed during the growth or dissolution of opal. Hence, we cannot derive a conservation equation equivalent to Eq. 1 for $\mathrm{Si}$ and DO.

\section{Results for the water mass distribution in the upper ocean and sources for the lower ocean}

The water distribution along with the circulation patterns in the upper ocean were used to validate the HAAC data to ensure that the HAAC is a reliable source of data covering a period of around half a century. An additional objective was to identify the routes by which water could potentially travel from the upper ocean to the lower ocean. In general, ocean nutrient levels are dependent on the circulation of the ocean, along with biological production/respiration, inflow from rivers, and sediment pore water. A large amount of fresh water (about $10 \%$ of the world's input from rivers into the oceans) flows into the Arctic Ocean (e.g., Yamamoto-Kawai et al. 2005). The horizontal distribution of Si concentration shows a belt of high concentration over the continental shelf in the Chukchi and the Laptev seas (figure not shown), although minor seasonal variations occur in the Si concentration, even in the upper ocean (Toole et al. 2010). The major source of $\mathrm{Si}$ in the Arctic Ocean is the Bering Sea, via the Bering Strait (Mathis 2014). The Bering Sea has high Si levels due to the influence of the deep water in the North Pacific as well as the Yukon River. The high-Si river waters of the $\mathrm{Ob}$ and Lena flow into the Kara and the Laptev seas.

The horizontal distribution of $\mathrm{Si}$ at a depth of $200 \mathrm{~m}$ is shown in Fig. 4a, and a cross-section through the Canada Basin showing the distribution of $\mathrm{Si}$ is presented in Fig. 5. Below $50 \mathrm{~m}$ depth, Si levels are generally high in the Canada Basin (around $35 \mu \mathrm{mol} / \mathrm{L}$ ) and low in the Eurasian Basin (below $10 \mu \mathrm{mol} / \mathrm{L}$ ). The highest levels of $\mathrm{Si}$ are seen at around $200 \mathrm{~m}$ and $300 \mathrm{~m}$ (no figure) in the southern portion 

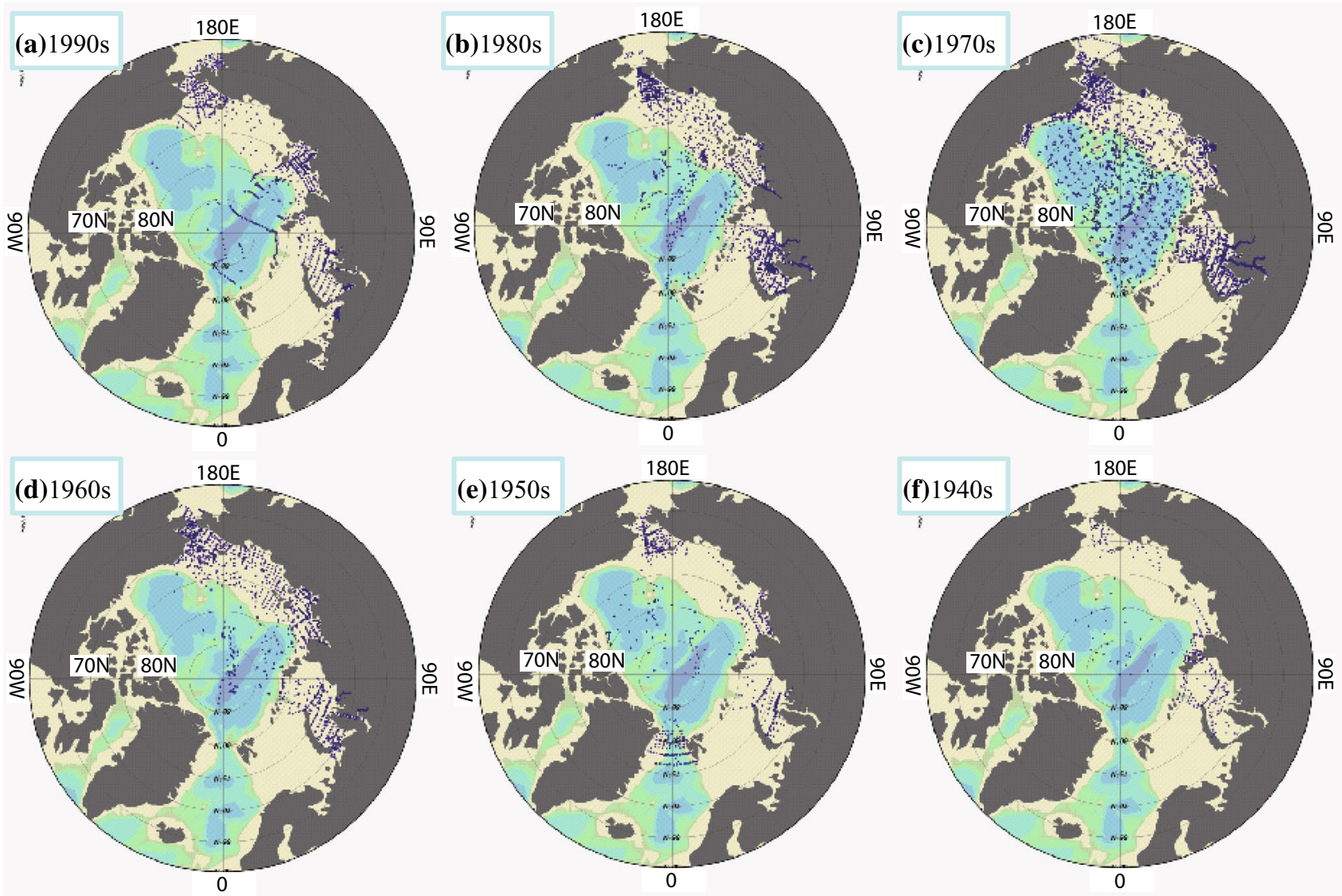

Fig. 3a-f The locations of observations performed in the Arctic Ocean during the a 1990s, b 1980s, c 1970s, d 1960s, e 1950s, and f 1940s

of the Canada Basin. This layer corresponds to the upper halocline water as defined by the nutrient maxima (e.g., Anderson et al. 1994). Such high levels of Si are not seen at a depth of $500 \mathrm{~m}$ (Fig. 4b). There is a clear gradient in $\mathrm{Si}$ concentration between the Amerasian side and the Eurasian side.

In the vertical distribution of $\mathrm{Si}$ shown in Fig. 5, the coastal region can be seen to have a maximum of $>55 \mu \mathrm{mol} / \mathrm{L}$. If the $\mathrm{Si}$ concentration of the upper halocline water is defined as $>20 \mu \mathrm{mol} / \mathrm{L}$, the thickness of this layer is about $100-200 \mathrm{~m}$. The upper halocline water is deepest at the center of the Canada Basin. In the vertical distribution pattern, the contour for $\mathrm{Si}=30 \mu \mathrm{mol} / \mathrm{L}$ matches the contour for a salinity of 34.0 (Sect. 4.5 in Frolov et al. 2005). This pattern has been confirmed using other data sources (e.g., Jones 2001) and is consistent with the Beaufort Gyre, which circulates anticyclonically and retains the less saline Pacific Water under the influence of wind stress. The horizontal distribution patterns for salinity (Fig. 2a) and Si (Fig. 4a) are well correlated. Here, we should remark that wind forcing induces mainly interannual fluctuations (e.g., Rudels 2012; Ikeda 2014; Yoshizawa et al. 2015). Since the observation dates of the HAAC dataset are biased towards the late 1970s, it is possible that the upper ocean of the Canada Basin was affected by a weaker polar vortex (a cyclonic atmospheric circulation around the North Pole) due to low Ekman divergence during the late 1970s (Ikeda et al. 2005).

The horizontal distribution of Si at depths of 200 to $500 \mathrm{~m}$ presents a clear boundary between the Pacific side and the Atlantic side. In this study, we defined the straight line that crosses the North Pole and passes through the steepest horizontal gradient in $\mathrm{Si}$ concentration as the Pacific-Atlantic Boundary (PAB; depicted as red dashed lines in Fig. 4). At $200 \mathrm{~m}$ depth (Fig. 4a), this boundary passed over the Lomonosov Ridge $\left(140^{\circ} \mathrm{E}-40^{\circ} \mathrm{W}\right)$, in accord with the results of Anderson et al. (1994). The boundary is also in line with the steep gradient in the water density and hence the dynamic topography called the Transpolar Drift Stream (e.g., Rudels 2012). The angle of the PAB shifts counterclockwise with depth (Fig. 4b). Also, the PAB presents decadal variability which is associated with the NAM, the first EOF mode (e.g., Ikeda 2014), and the decadal mean for the 1970s is similar to the mean state of the PAB over the half-century of observations.

According to previous studies (e.g., Rudels 2012), in the upper ocean, the surface layer above the upper halocline 


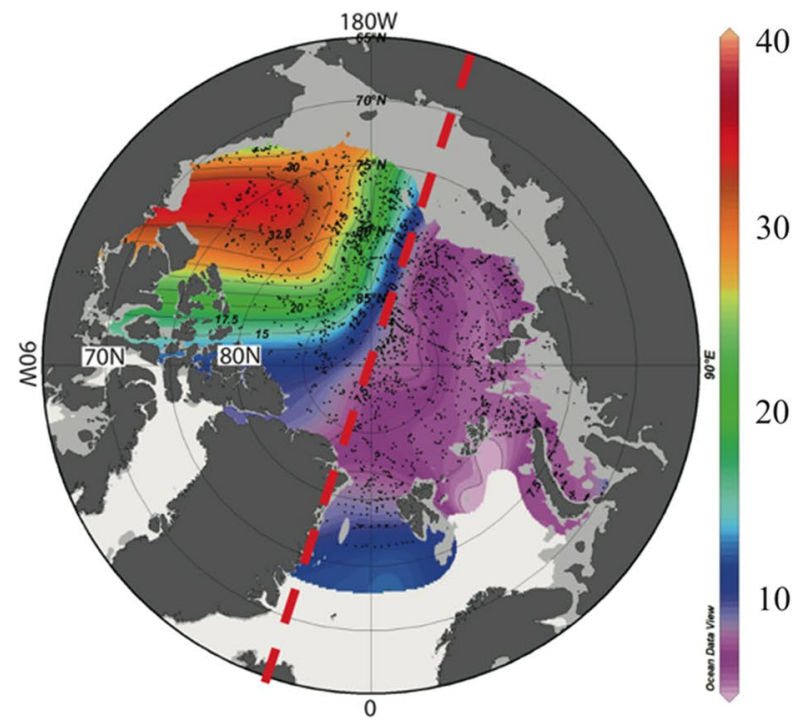

(a) $200 \mathrm{~m}$

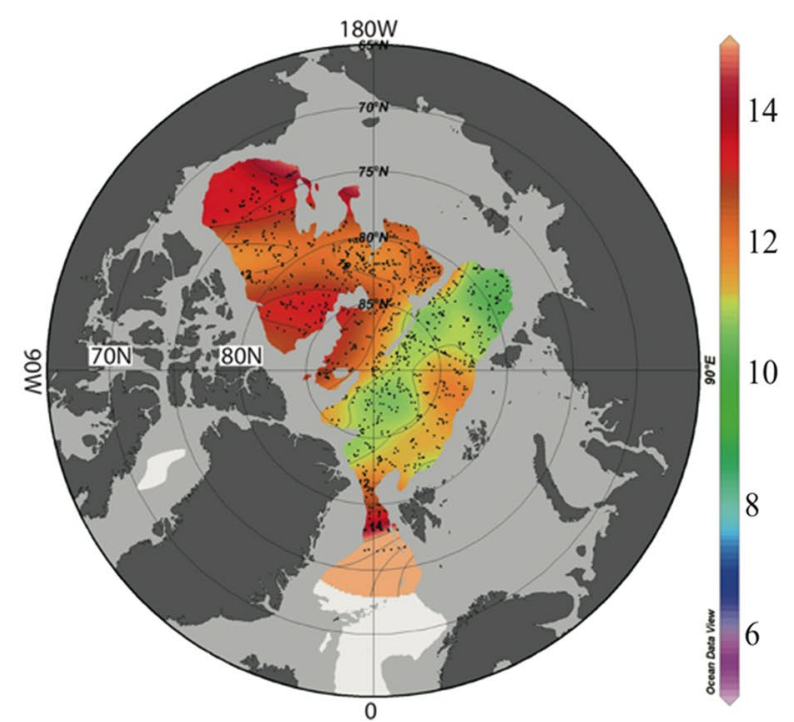

(c) $2000 \mathrm{~m}$

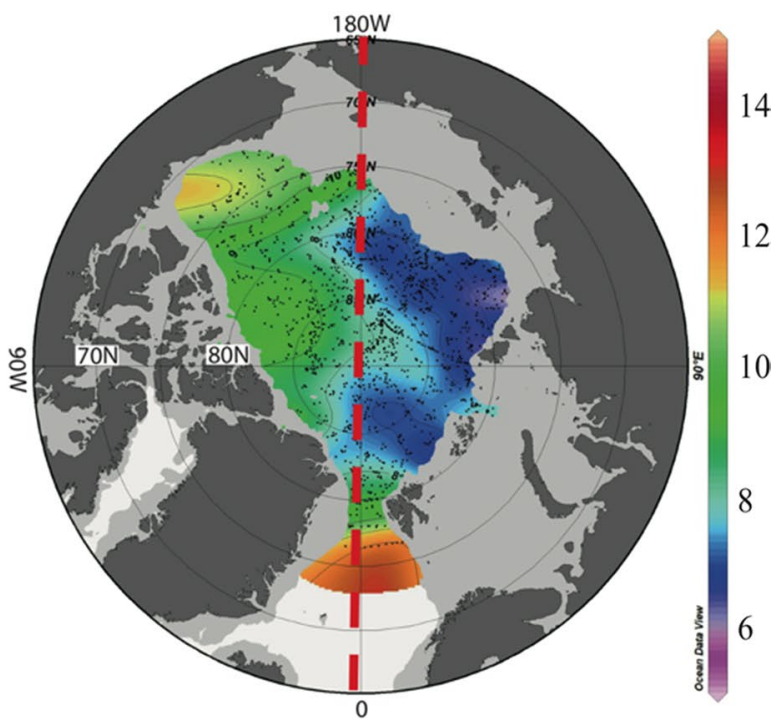

(b) $500 \mathrm{~m}$

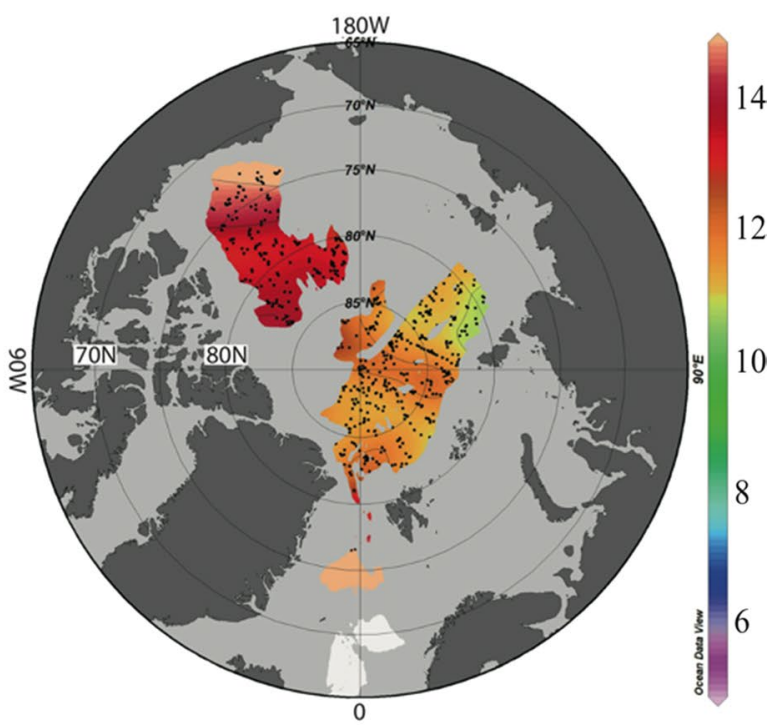

(d) $3000 \mathrm{~m}$

Fig. 4a-d The horizontal distribution of $\mathrm{Si}(\mu \mathrm{mol} / \mathrm{L})$ at depths of a $200 \mathrm{~m}, \mathbf{b} 500 \mathrm{~m}, \mathbf{c} 2000 \mathrm{~m}$, and d $3000 \mathrm{~m}$. The red dashed lines in a and b indicate the Pacific-Atlantic Boundary (PAB)

water circulates anticyclonically in the Canada Basin and then flows along the Transpolar Drift Stream towards the Atlantic Ocean (see Fig. 1a, c). The Atlantic Water replaces the Pacific Water under the Transpolar Drift Stream and circulates cyclonically from the Eurasian Basin to the Amerasian Basin. Hence, the vertical shift in the angle of the PAB is qualitatively consistent with this buoyancy-driven circulation, and is also supported by a dynamic model (Spall 2013). The Upper Polar Deep Water flow that travels from the Arctic Ocean toward the Atlantic (Fig. 1b, c) can be attributed to the reversed density difference as the depth increases, as the Atlantic Water is lighter than the Arctic Water (Rudels 2012). The Atlantic Water forms a boundary current that circulates cyclonically around the shelf break from the Barents Sea to the Siberian shelf (Rudels et al. 2015). The reversal of flow from the Arctic Ocean to the Atlantic Ocean occurs at a depth of around $1000 \mathrm{~m}$ on the North American side.

Other geochemical parameters, phosphate and dissolved oxygen, were also examined to verify the ocean circulation derived from the distribution of $\mathrm{Si}$ in the upper ocean. The $\mathrm{PO}_{4}$ distributions at depths of 200 and $500 \mathrm{~m}$ are shown in Fig. 6 and are consistent with other sources of such data 
Fig. 5 A cross-section of the Canada Basin showing the $\mathrm{Si}(\mu \mathrm{mol} / \mathrm{L})$ distribution. The origin of this cross-section is located at $74^{\circ} \mathrm{N}, 180^{\circ} \mathrm{W}$, and extends along the red line shown on the map below the cross-section
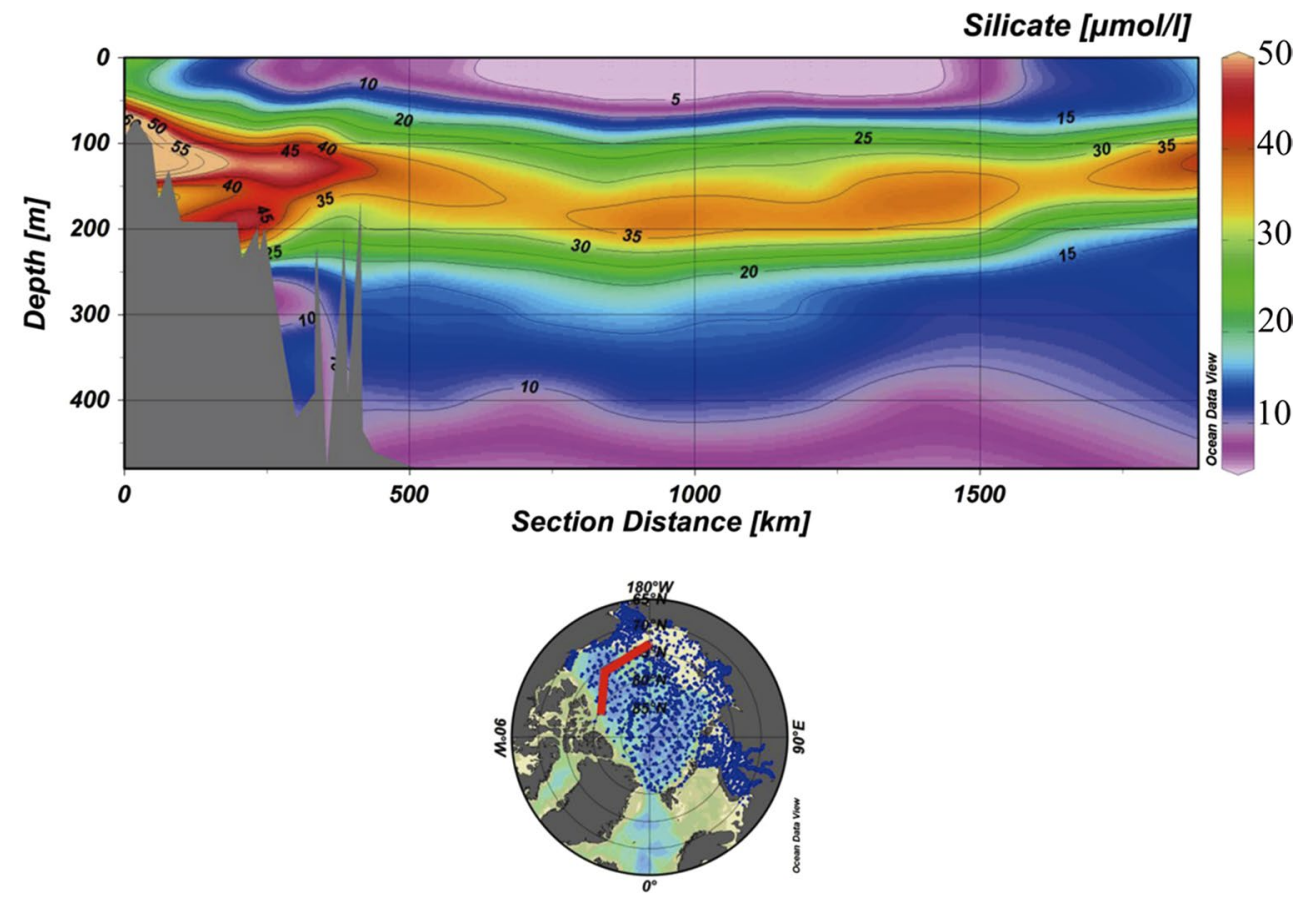

contains heavier water and was fully reviewed by Smedsrud et al. (2013) as a source of deep water in the Amerasian Basin. Lien and Trofimov (2013) observed that the bottom water over the St. Anna Trough in the northern Barents Sea flows down to a depth of $2000 \mathrm{~m}$ in the Arctic Ocean. As it drops, its density increases due to the compression caused by the increasing pressure. Arthun et al. (2011) examined the ocean water flux from the Atlantic Ocean through the Barents Sea to the deep part of the Arctic Ocean using a coupled ice-ocean model. The water mass containing the brine rejected from sea ice formation tends to spread along the shelf break, where its distribution varies over time and space such that the denser part sometimes flows down along the shelf break beyond the Atlantic Water (A-Water) layer. The A-Water moves along the Siberian shelf towards the Chukchi and Beaufort Seas, as observed by Smethie et al. (2000) and modeled by Aksenov et al. (2011). Karcher et al. (2012) reported that the A-Water sometimes reached the Chukchi and Beaufort Seas due to NAM variability, while Pnyushkov et al. (2015) observed its spread within the Canada Basin.

In Sect. 4, possible routes for certain water masses in the lower ocean of the Amerasian and Eurasian basins are identified using $\mathrm{PO}_{4}$ *. We categorize the sources of those masses here on the basis of the $\mathrm{PO}_{4} *$ values in the upper ocean. The geochemical properties off the northern part of the Barents Sea can be derived from the HAAC dataset: $\mathrm{PO}_{4}$ and DO are 0.80 and $310 \mu \mathrm{mol} / \mathrm{L}$ at $200 \mathrm{~m}$, respectively (Figs. 6a, 7a), and $\mathrm{PO}_{4}$ and DO are $0.75 \mu \mathrm{mol} / \mathrm{L}$ and $320 \mu \mathrm{mol} / \mathrm{L}$ at $500 \mathrm{~m}$, respectively (Figs. 6b, 7b). Applying Eq. 1, we calculated $\mathrm{PO}_{4} *$ as $0.60 \mu \mathrm{mol} / \mathrm{L}$ in the layer between 200 and $500 \mathrm{~m}$. These values are summarized in 


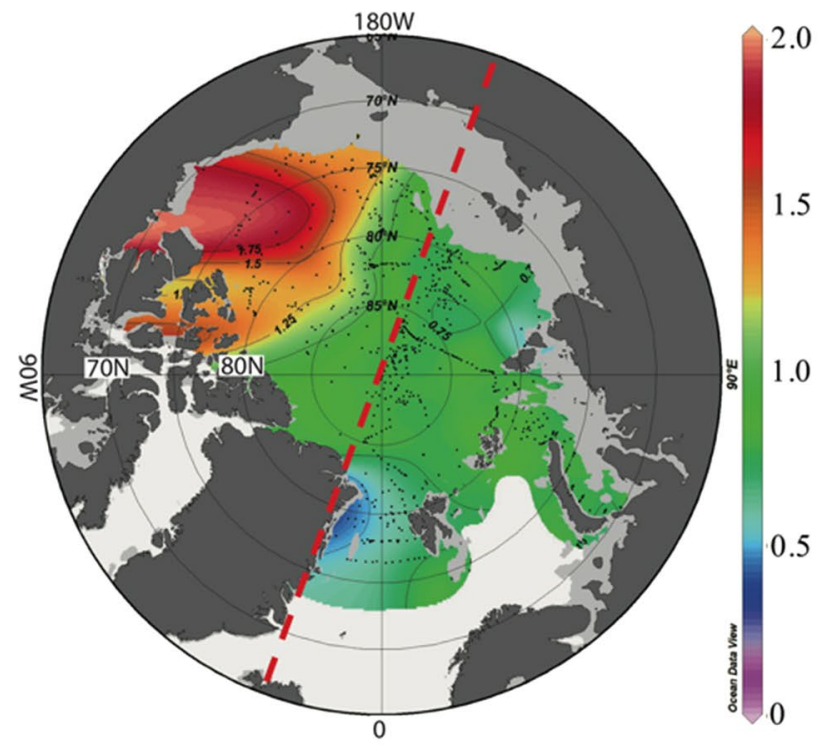

(a) $200 \mathrm{~m}$

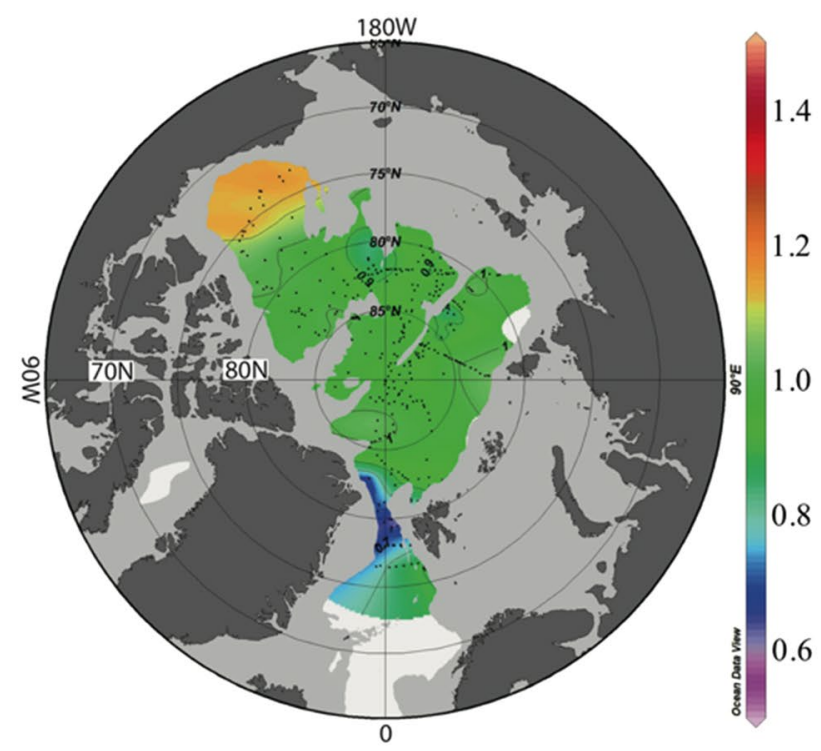

(c) $2000 \mathrm{~m}$

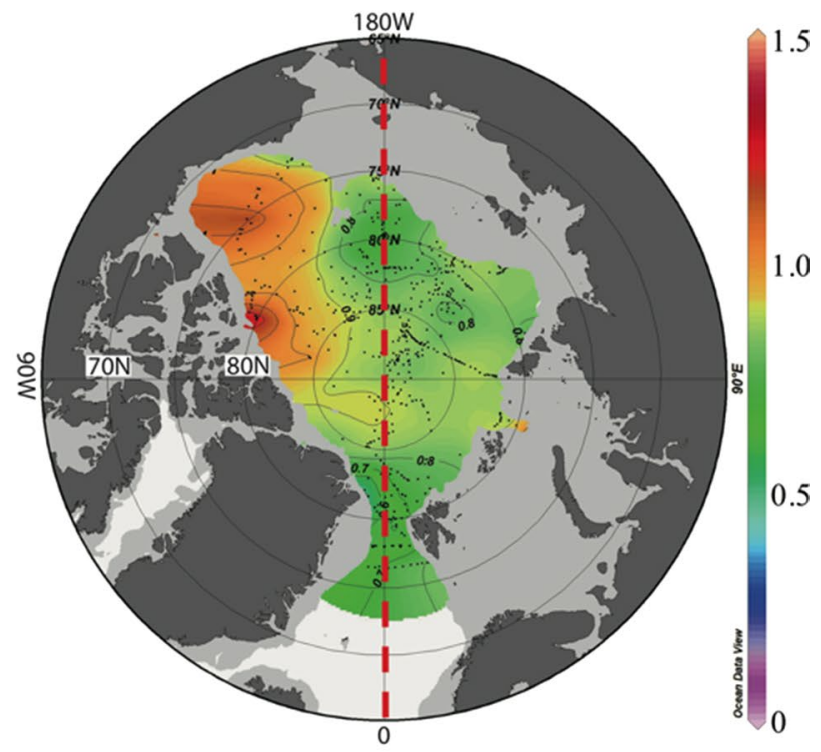

(b) $500 \mathrm{~m}$

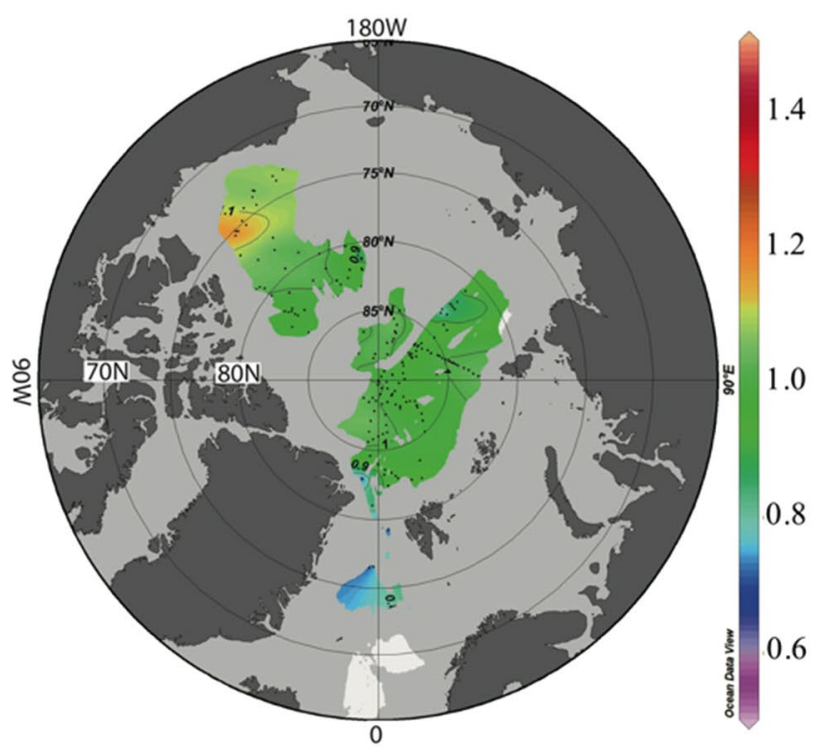

(d) $3000 \mathrm{~m}$

Fig. 6a-d The horizontal distribution of $\mathrm{PO}_{4}(\mu \mathrm{mol} / \mathrm{L})$ at depths of a $200 \mathrm{~m}, \mathbf{b} 500 \mathrm{~m}, \mathbf{c} 2000 \mathrm{~m}$, and $\mathbf{d} 3000 \mathrm{~m}$. The red dashed lines in a and b indicate the Pacific-Atlantic Boundary $(P A B)$

Table 1. Accounting for the spatial and temporal variability yields a standard error of $0.03 \mu \mathrm{mol} / \mathrm{L}$ in the value of $\mathrm{PO}_{4}{ }^{*}$. Following the same procedure, the value of $\mathrm{PO}_{4}{ }^{*}$ is $0.69 \mu \mathrm{mol} / \mathrm{L}$ at $200 \mathrm{~m}$ depth in the Fram Strait. For the shelf areas from the Laptev Sea to the Barents Sea, representative values for the upper ocean (averages of the values at depths of $200 \mathrm{~m}$ and $150 \mathrm{~m}$ ) are listed in Table 1. The highest value $(1.48 \mu \mathrm{mol} / \mathrm{L})$, attributable to high $\mathrm{PO}_{4}$, was found for the 150-200 m layer in the Chukchi and
Beaufort seas, while a much lower value $(0.59 \mu \mathrm{mol} / \mathrm{L})$ was calculated for the 150-200 m layer in the northern part of the Laptev Sea, away from the Bering Strait. The values of $\mathrm{PO}_{4} *$ in the Barents Sea are similar to those in the Laptev Sea. It should be noted that DO can be replenished via the sea surface during the remineralization of organic matter, while $\mathrm{PO}_{4}{ }^{*}$ is conserved during the downward movement. These $\mathrm{PO}_{4}{ }^{*}$ values will be compared with those in lower ocean fields in order to identify candidates 


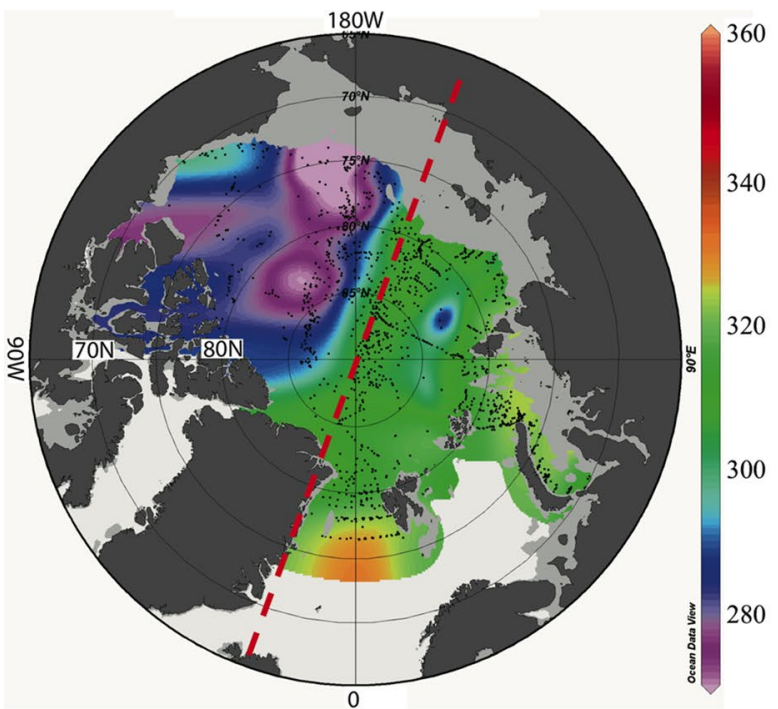

(a) $200 \mathrm{~m}$

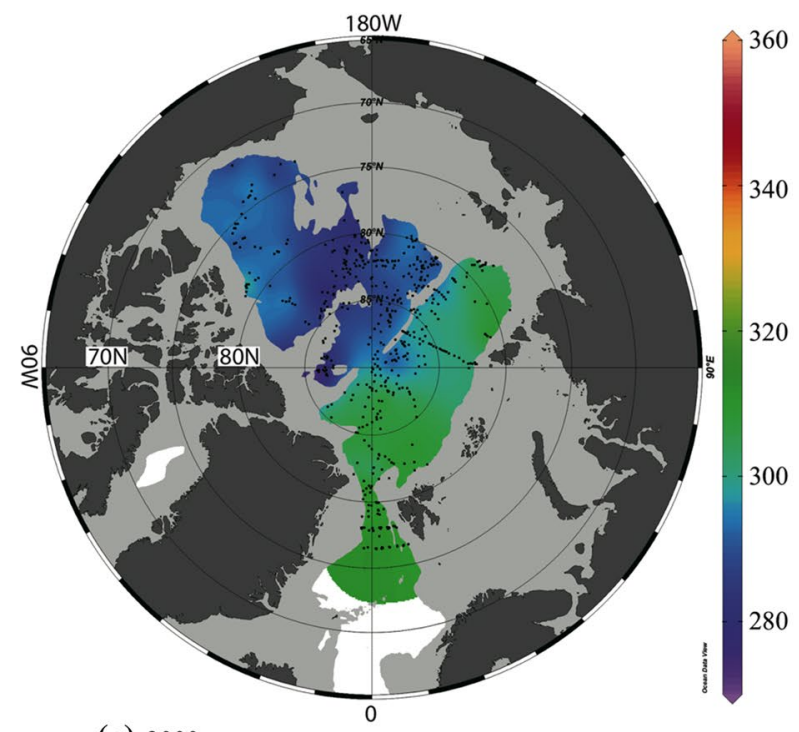

(c) $2000 \mathrm{~m}$

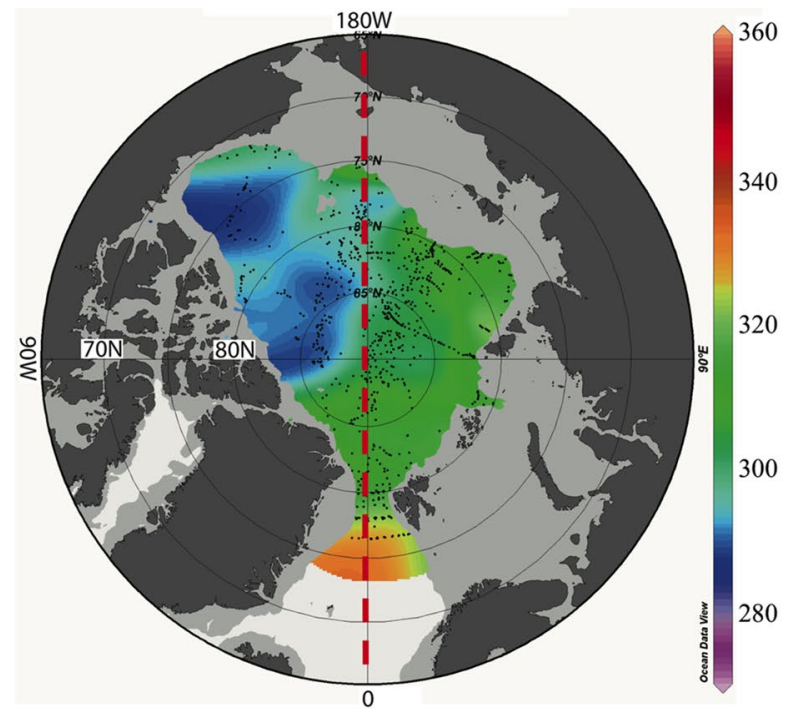

(b) $500 \mathrm{~m}$

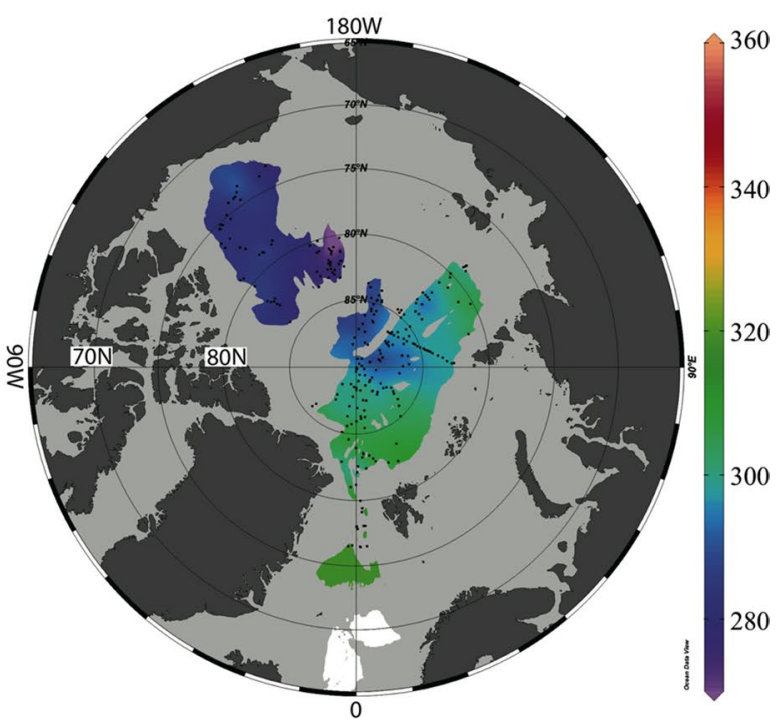

(d) $3000 \mathrm{~m}$

Fig. 7a-d The horizontal distribution of DO ( $\mu \mathrm{mol} / \mathrm{L})$ at depths of a $200 \mathrm{~m}, \mathbf{b} 500 \mathrm{~m}, \mathbf{c} 2000 \mathrm{~m}$, and $\mathbf{d} 3000 \mathrm{~m}$. The red dotted lines in a and b indicate the Pacific-Atlantic Boundary (PAB)

for the source water of the Amerasian and Eurasian basins in the next section.

\section{Results for water properties in and routes to the intermediate layer and the lower ocean}

In this section, the origins and routes of the water masses in the lower ocean and the intermediate layer are proposed, based on analyses of the $\mathrm{Si}, \mathrm{PO}_{4}, \mathrm{DO}$, and $\mathrm{PO}_{4}{ }^{*}$ distributions. Determining the horizontal distributions of these geochemical components allows us to probe the fundamental inflow patterns from the Fram Strait and the merging of this water with the intermediate layer as it heads toward the Atlantic Ocean. Vertical profiles are also obtained by averaging the components separately on the Pacific and Atlantic sides so that possible routes from the upper ocean to the lower ocean can be discerned. Finally, statistically analyzing the distribution of $\mathrm{PO}_{4}{ }^{*}$ in the lower ocean permits the identification of the most probable routes from the upper to the lower ocean.

The circulation patterns in the intermediate layer and the lower ocean are shown in Fig. 1b and c. These patterns 


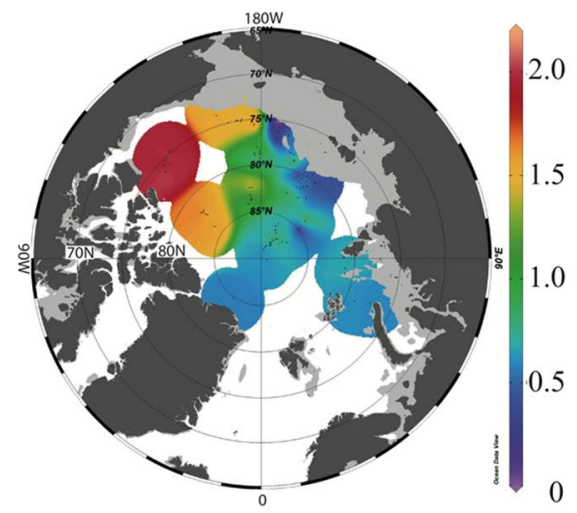

(a) $150 \mathrm{~m}$

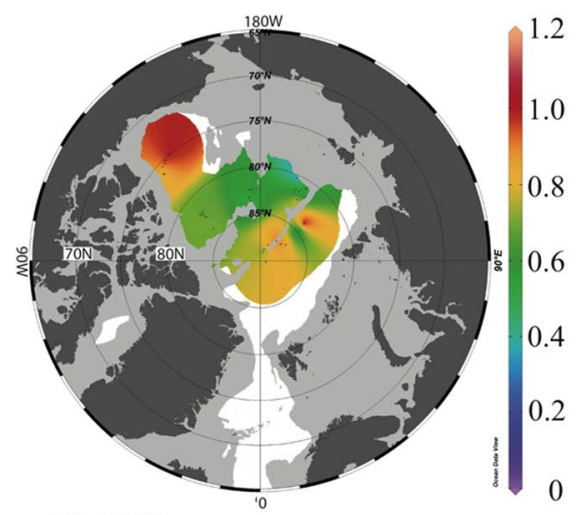

(d) $2000 \mathrm{~m}$

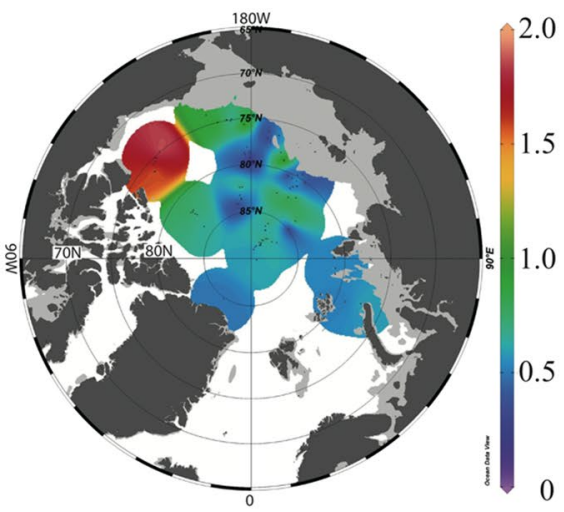

(b) $200 \mathrm{~m}$

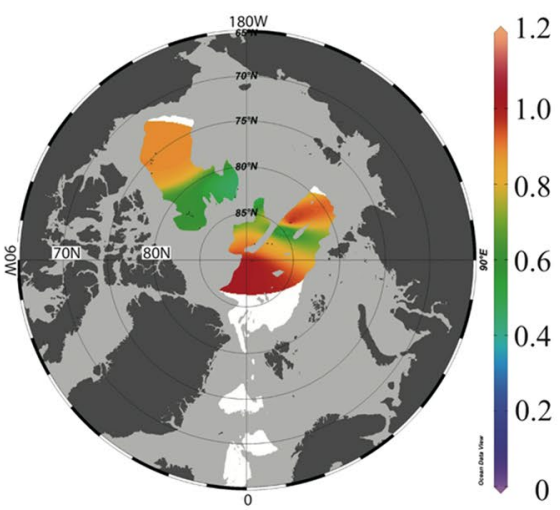

(e) $3000 \mathrm{~m}$

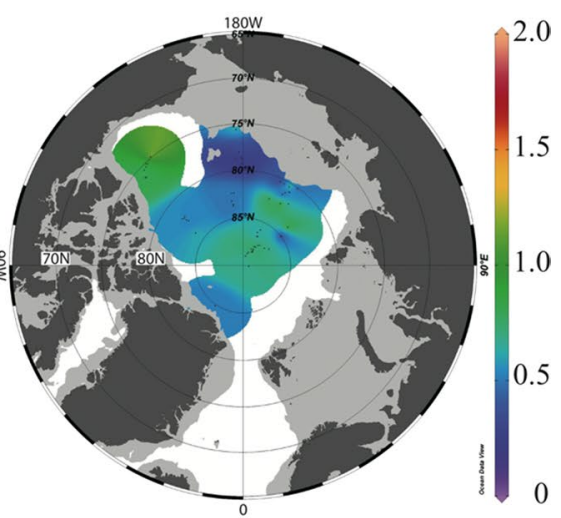

(c) $500 \mathrm{~m}$

Fig. 8a-c The horizontal distribution of $\mathrm{PO}_{4} *(\mu \mathrm{mol} / \mathrm{L})$ at depths of a $150 \mathrm{~m}, \mathbf{b} 200 \mathrm{~m}, \mathbf{c} 500 \mathrm{~m}$, and d $2000 \mathrm{~m}$ and e $3000 \mathrm{~m}$. Since data points are sparse, an extrapolation radius of $300 \mathrm{~km}$ has been applied. Note that the color scales used in $\mathbf{a}, \mathbf{b}, \mathbf{c}$ differ from those used in $\mathbf{d}, \mathbf{e}$

Table 1 Values of $\mathrm{PO}_{4}, \mathrm{DO}$, and $\mathrm{PO}_{4} *(\mu \mathrm{mol} / \mathrm{L})$ in the specified regions and at particular depths

\begin{tabular}{lllllll}
\hline $\begin{array}{l}\text { Abbreviation } \\
\text { for region }\end{array}$ & Region & Depth (m) & $\mathrm{PO}_{4}$ & $\mathrm{DO}$ & $\mathrm{PO}_{4}{ }^{*}$ & $S$ error \\
\hline $\mathrm{CB}$ & Chukchi and Beaufort seas & $150-200$ & 1.84 & 277 & 1.48 & 0.10 \\
$\mathrm{~L}$ & Northern part of the Laptev Sea & $150-200$ & 0.78 & 305 & 0.59 & 0.07 \\
$\mathrm{C}$ & Canada Basin (high-PO ${ }_{4}$ area) & $2000-4000$ & 1.15 & 295 & 0.90 & 0.03 \\
$\mathrm{~A}$ & Amerasian Basin excluding Region C & $2000-4000$ & 0.90 & 285 & 0.58 & 0.02 \\
$\mathrm{E}$ & Eurasian Basin & $2000-4000$ & 0.95 & 310 & 0.78 & 0.06 \\
$\mathrm{~B}$ & Northern part of Barents Sea & $200-500$ & 0.80 & 310 & 0.60 & 0.03 \\
& Greenland Sea (Fram Strait) & 500 & 0.70 & 340 & 0.69 & \\
& Greenland Sea (Fram Strait) & 2000 & 0.70 & 310 & 0.52 & \\
\hline
\end{tabular}

In the lower ocean below $2000 \mathrm{~m}$, region $\mathrm{C}$ with high $\mathrm{PO}_{4}$ in the Canada Basin is located between $150^{\circ} \mathrm{W}$ and $120^{\circ} \mathrm{W}$, and south of $80^{\circ} \mathrm{N}$. Region A denotes the Amerasian Basin (excluding region C), and region $\mathrm{E}$ is the Eurasian Basin. Region $\mathrm{CB}$ in the upper ocean denotes the layer at 150-200 $\mathrm{m}$ depth and $70^{\circ} \mathrm{N}-80^{\circ} \mathrm{N}, 130^{\circ} \mathrm{W}-175^{\circ} \mathrm{W}$ in the Chukchi and Beaufort seas. Region L denotes the layer at $150-200 \mathrm{~m}$ depth and at $75^{\circ} \mathrm{N}-85^{\circ} \mathrm{N}, 90^{\circ} \mathrm{E}-170^{\circ} \mathrm{E}$ in the Laptev Sea. Region B is the layer at $200-500 \mathrm{~m}$ depth and at $75^{\circ} \mathrm{N}-85^{\circ} \mathrm{N}, 0^{\circ}-90^{\circ} \mathrm{E}$ in the Barents Sea. For these regions, the values of $\mathrm{PO}_{4} *$ were calculated from values of $\mathrm{PO}_{4}$ and $\mathrm{DO}$ measured at the same location. The means of and standard errors in $\mathrm{PO}_{4}{ }^{*}$ were calculated from the data. For the Fram Strait, $\mathrm{PO}_{4}{ }^{*}$ values were estimated from the independently measured fields of $\mathrm{PO}_{4}$ and DO, which are plotted in Figs. 6 and 7, respectively 
are based on research results from various studies, including Aagaard et al. (1985), Jones (2001), Timmermans et al. (2005), and Rudels (2012). The Nordic Seas Deep Water originates from the North Atlantic Deep Water and flows into the Arctic Ocean via the Fram Strait. This over-sill flow is only $0.25 \mathrm{~Sv}$, or $10 \%$ of the A-Water in the subsurface portion of the upper ocean. This water travels along the bottom from the Amundsen Basin to the Makarov Basin, affecting the lower ocean in the Amerasian Basin. In addition to this generally accepted circulation pattern, some material and water fluxes have been suggested and are targeted for verification in the present study using the HAAC dataset. The lower ocean receives organic matter from the upper ocean and the dense shelf water which is rich with nutrients. The lower-ocean water mass gradually returns to the Eurasian Basin as the Upper Polar Deep Water by mixing with the subsurface A-Water.

The horizontal temperature and salinity distributions at depths of 2000 and $3000 \mathrm{~m}$ are shown in Fig. 2. The fundamental structure highlights differences in the physical parameters between the Amundsen Basin and the Makarov Basin. The water is slightly heavier, colder, and less saline in the Amundsen Basin than in the Makarov Basin, and flows towards the Makarov Basin. This flow pattern is consistent with that depicted in a vertical plane by Timmermans et al. (2005). Small-scale features are present in both basins, and may indicate perturbations in intermittent overflows toward the Makarov Basin and downward flows from the upper ocean.

In this section, the lower ocean below a depth of $1500 \mathrm{~m}$ is clarified and some detailed descriptions of geochemical components and flow fields are provided, and then the intermediate layer is described as a downstream component of the upper and lower oceans.

The distribution of Si at $2000 \mathrm{~m}$ (Fig. 4c) is qualitatively consistent with two of the circulation patterns described above. The low-Si belt in the Amundsen Basin is due to the flow of the Nordic Seas Deep Water from the Greenland Sea into the Arctic Ocean. The high-Si region in the Canada Basin has been attributed to the dissolution of sinking biological material (opal) from the coastal area off Alaska (Mathis 2014), while additional input from both biological material and downward water flows is visible on the northern side of the Barents Sea (Fig. 4c, d). In the distribution of $\mathrm{PO}_{4}$ at $2000 \mathrm{~m}$ depth (Fig. 6c), the Nordic Seas Deep Water is clearly visible in the Greenland Sea but less visible in the Amundsen Basin (due to the input from the Barents Sea) and even less distinct in the southern Canada Basin. The DO distributions at 2000 and $3000 \mathrm{~m}$ show a high-DO source in the northern Greenland Sea which is decreased in the Amundsen Basin and further reduced off the Beaufort Sea shelf area (Fig. 7c, d).
The horizontal distribution of $\mathrm{PO}_{4} *$ in the lower ocean shows a high- $\mathrm{PO}_{4} *$ core in the southern part of the Canada Basin (Fig. 8d, e), reflecting high values of $\mathrm{PO}_{4}$ in this region (Fig. 6c, d). The $\mathrm{PO}_{4}{ }^{*}$ levels are lower in the northern part of the Amerasian Basin than in the Amundsen Basin, which is attributable to lower DO (Fig. 7c). As explained in the footnotes for Table 1, due to a lack of $\mathrm{PO}_{4}{ }^{*}$ data for the Fram Strait, $\mathrm{PO}_{4}$ * values were calculated for this region from the horizontal distributions of $\mathrm{PO}_{4}$ (Fig. 6) and DO (Fig. 7) in the strait, and the values were found to increase as the water flowed into the Eurasian Basin. High $\mathrm{PO}_{4}{ }^{*}$ occurs from the Greenland side along the bottom of the Eurasian Basin (Fig. 8e), although this region contains only a few data points, suggesting the need for careful interpretation.

Next we examine the vertical profiles. Data on chemical components other than $\mathrm{Si}$ are rather sparse, so the horizontal mean values on the Pacific and Atlantic sides were examined in the present study. The two sides were separated by the $\mathrm{PAB}$ in the upper ocean, while the meridional line $\left(0^{\circ}-180^{\circ}\right)$ was the dividing line in the intermediate layer and the Lomonosov Ridge was used for the lower ocean. The vertical profiles of $\mathrm{Si}, \mathrm{DO}$, and $\mathrm{PO}_{4}$ are shown in Fig. 9. The $\mathrm{PO}_{4} *$ (which is conserved during the consumption of DO according to Eq. 1, as discussed in Sect. 2.2) profiles for the Pacific and Atlantic sides are shown in Fig. 10.

We now turn our attention to the vertical profiles in the upper ocean, as they provide the baseline for confirming generally accepted biogeochemical processes through comparison with the vertical salinity profile (Fig. 8 of Rudels 2012). $\mathrm{Si}$ and $\mathrm{PO}_{4}$ show very similar patterns. Around the bottom of the winter surface mixed layer above the upper halocline, both $\mathrm{Si}$ and $\mathrm{PO}_{4}$ show peaks at around $150 \mathrm{~m}$ depth on the Pacific side only. On the other hand, the DO distributions on both sides are qualitatively similar, although much more distinct features are observed on the Pacific side than on the Atlantic side. The vertical DO profiles show high values in the first $50 \mathrm{~m}$ below the surface, and low values around the upper halocline. When the temperature in the surface layer was close to freezing, the saturation concentration was about $370 \mu \mathrm{mol} / \mathrm{L}$ (Garcia and Gordon 1994), indicating near-saturated states on both sides. The main cause of the DO minima is the consumption of DO during remineralization. The DO values shown here are in reasonable agreement with those from other sources (e.g., Falkner et al. 2005; McLaughlin et al. 2011). The $\mathrm{PO}_{4}$ values are also consistent with more recent data (Brown et al. 2016). On the Pacific side, due to the remineralization process, biological materials from the Pacific Ocean rapidly supply $\mathrm{PO}_{4}$ to seawater below the surface mixed layer due to the consumption of DO. Therefore, $\mathrm{PO}_{4}{ }^{*}$ has a gentler gradient of $-0.2 \mu \mathrm{mol} / \mathrm{L}$ (Fig. 9c) than $\mathrm{PO}_{4}$ (gradient: $-0.6 \mu \mathrm{mol} / \mathrm{L}$ ) (Fig. 10) in the 100 -m-thick surface mixed layer. Air-sea oxygen flux takes place at the sea surface even after DO consumption, contributing to a 

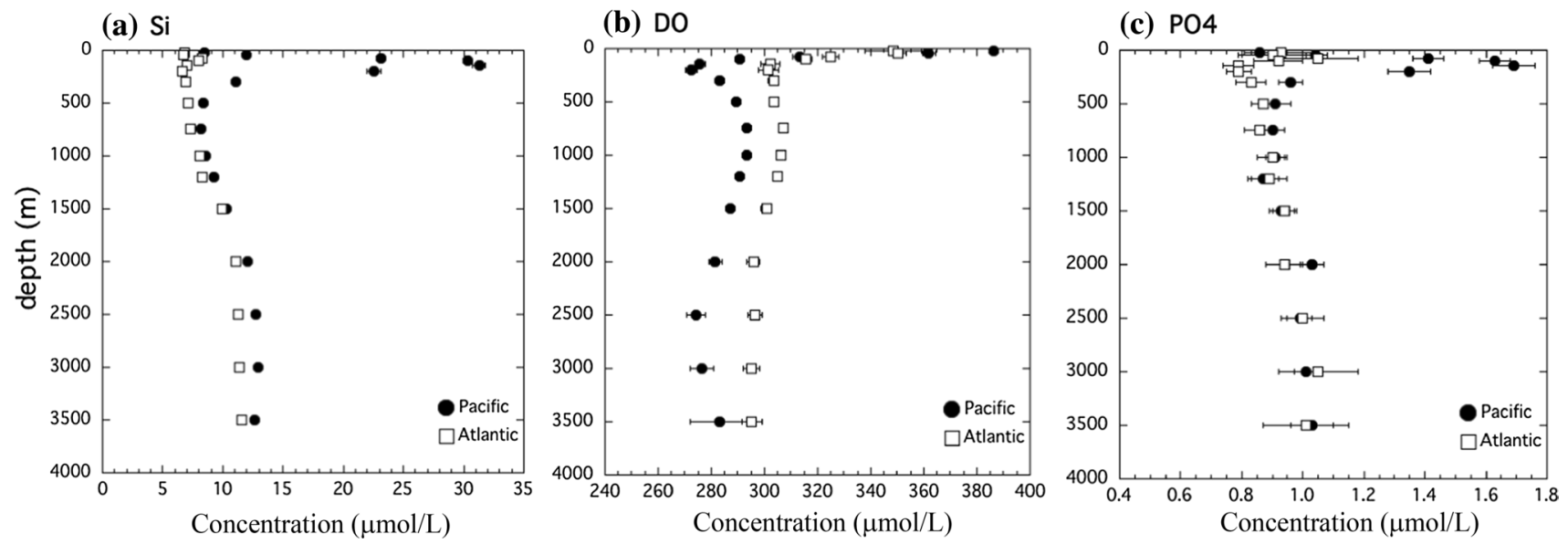

Fig. 9a-c Horizontal mean values of a $\mathrm{Si}(\mu \mathrm{mol} / \mathrm{L})$, b DO $(\mu \mathrm{mol} / \mathrm{L})$, and $\mathbf{c} \mathrm{PO}_{4}(\mu \mathrm{mol} / \mathrm{L})$ on the Pacific and Atlantic sides. The values are plotted at the exact depths from which the data were taken and averaged. The Pacific and Atlantic sides are separated by the PAB between the sea surface and $500 \mathrm{~m}$ depth, by the $0^{\circ}-180^{\circ}$

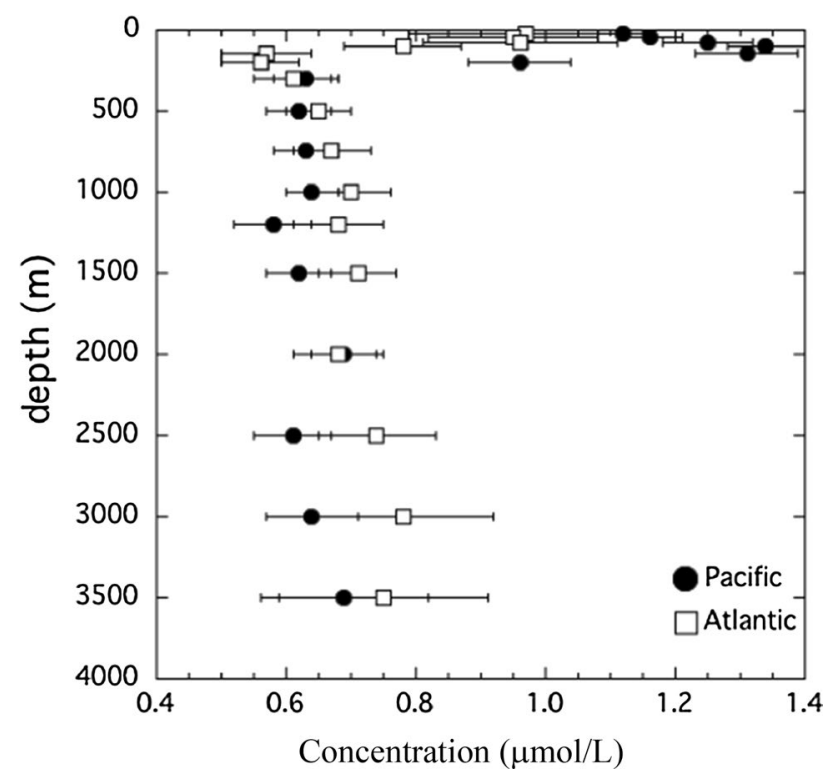

Fig. 10 Vertical $\mathrm{PO}_{4}{ }^{*}(\mu \mathrm{mol} / \mathrm{L})$ profiles for the Pacific and Atlantic sides. The error bar for each mean value indicates the standard error in the data used to calculate the mean

further increase in $\mathrm{PO}_{4}{ }^{*}$. On the Atlantic side, there is no sharp $\mathrm{PO}_{4}^{*}$ gradient (the highest level, $0.2 \mu \mathrm{mol} / \mathrm{L}$, occurs within the 100-m-thick surface mixed layer) except for the increase due to the air-sea oxygen flux. Near the sea surface (above a depth of $50 \mathrm{~m}$ ), the difference in $\mathrm{PO}_{4}$ * between the Amerasian and the Eurasian basins is small, due to mirror symmetry based on remineralization (Figs. 9, 10). However, the $\mathrm{PO}_{4}{ }^{*}$ levels in the upper ocean are higher in the Amerasian Basin than in the Eurasian Basin. line between 500 and $1500 \mathrm{~m}$, and by the Lomonosov Ridge below $1500 \mathrm{~m}$. Error bars indicate the standard error associated with the horizontal variability. Note that analytical errors arising from the device used to obtain the data need to be accounted for (see also Sect. 2)

If we examine the intermediate layer (500-1500 m) and the lower ocean (below $1500 \mathrm{~m}$ ) in the vertical profiles, we see that the Si concentration is higher on the Pacific side than on the Atlantic side, consistent with the horizontal distributions. On the other hand, $\mathrm{PO}_{4}$ is higher on the Pacific side at $500 \mathrm{~m}$ depth, while there are only minor differences between the two basins in the deeper part, except at $2000 \mathrm{~m}$ depth (Fig. 9c). The extra $\mathrm{PO}_{4}$ can be attributed to the high- $\mathrm{PO}_{4}$ region in the southern part of the Canada Basin (Fig. 6c). In the intermediate layer and the lower ocean, the DO is higher by $15-20 \mu \mathrm{mol} / \mathrm{L}$ on the Atlantic side than on the Pacific side. The A-Water has high DO levels, and shows relatively weak consumption effects in the subsurface portion of the upper ocean and the downward flow from the continental shelf. There is less $\mathrm{PO}_{4} *$ in the lower ocean on the Pacific side than on the Atlantic side, while very similar levels occur in the intermediate layers on the Pacific side and the Atlantic side. Therefore, it is reasonable to propose that the intermediate layers on both sides have a common origin, which is likely the lower ocean on the Pacific side.

The Nordic Seas Deep Water also exhibits weak consumption effects. Below $1000 \mathrm{~m}$, the DO concentration decreases with depth very gradually on the Atlantic side, while a minimum DO exists at around $2500 \mathrm{~m}$ depth on the Pacific side (Fig. 9b). The distribution pattern in the intermediate layer reflects the contrast between the upper and lower oceans: the Nordic Seas Deep Water shows less movement than the A-Water in the upper ocean, remaining in the lower ocean on the Pacific side for centuries. The lower-ocean water mass gradually moves upward and/or mixes with the intermediate layer (Timmermans et al. 2005), becoming the source of the Upper Polar Deep Water, which 
mixes with the low- $\mathrm{PO}_{4} *$ A-Water in the upper ocean while flowing towards the Atlantic Ocean. Thus, the Upper Polar Deep Water contains $\mathrm{PO}_{4}$ * levels between those of the lower ocean and the subsurface A-Water (Fig. 10).

Finally, we now identify the sources of the lower-ocean water masses in the Amerasian Basin and the Eurasian Basin using $\mathrm{PO}_{4}{ }^{*}$ as a tracer (values of this parameter for various regions are listed in Table 1, and statistical results are shown in the "Appendix"). The Amerasian Basin is divided into two parts: the Canada Basin has a high- $\mathrm{PO}_{4}$ core and high $\mathrm{PO}_{4}{ }^{*}$ levels are also seen in the southern part of the Beaufort Sea (Figs. 6c, 8d). We define region $\mathrm{C}$ as that between $150^{\circ} \mathrm{W}$ and $120^{\circ} \mathrm{W}$ and south of $80^{\circ} \mathrm{N}$, while region $\mathrm{A}$ denotes the Amerasian Basin excluding region $\mathrm{C}$. The spatial mean values of $\mathrm{PO}_{4}{ }^{*}$ are $0.90 \mu \mathrm{mol} / \mathrm{L}$ in region $\mathrm{C}, 0.58 \mu \mathrm{mol} / \mathrm{L}$ in region $\mathrm{A}$, and $0.78 \mu \mathrm{mol} / \mathrm{L}$ in region $\mathrm{E}$, the Eurasian Basin. The spatial variability was evaluated by calculating the standard deviation for each region: $0.09-0.13 \mu \mathrm{mol} / \mathrm{L}$ in regions $\mathrm{C}$ and $\mathrm{A}$, and $0.3-0.5 \mu \mathrm{mol} / \mathrm{L}$ in region $\mathrm{E}$ ("Appendix"). Thus, region $\mathrm{E}$ contains a wide variety of water masses. Based on both Welch's $t$ test and the Mann-Whitney $U$ test, the mean value in region A is significantly different from the means in regions $\mathrm{C}$ and $\mathrm{E}$ at a significance level of $95 \%$. Hence, it is meaningful to separate the Amerasian Basin into regions $\mathrm{C}$ and $\mathrm{A}$.

It is logical to propose that the high- $\mathrm{PO}_{4} *$ core $\left(\mathrm{PO}_{4}{ }^{*}=0.87 \mu \mathrm{mol} / \mathrm{L}\right.$ at depths of $2000-2999 \mathrm{~m}$ and $0.95 \mu \mathrm{mol} / \mathrm{L}$ at depths of $3000 \mathrm{~m}$ to the bottom) in region $\mathrm{C}$ receives the sinking water mass from the Chukchi Sea along the continental slope. Region $\mathrm{A}$ has a mean $\mathrm{PO}_{4}{ }^{*}$ of $0.59 \mu \mathrm{mol} / \mathrm{L}$ at depths of $2000-2999 \mathrm{~m}$ and $0.57 \mu \mathrm{mol} / \mathrm{L}$ at depths of $3000 \mathrm{~m}$ to the bottom. One main difference between regions $\mathrm{C}$ and $\mathrm{A}$ is the $\mathrm{PO}_{4}{ }^{*}$ levels on the shelves adjacent to these regions: $1.12 \mu \mathrm{mol} / \mathrm{L}$ and $0.62 \mu \mathrm{mol} / \mathrm{L}$ along the shelves for the Chukchi and Beaufort seas and the Laptev Sea, respectively (Table 1). Previous studies have suggested the presence of sinking shelf water from the Beaufort Sea (Aagaard et al. 1985; Rudels 2012). We should examine the differences in salinity and temperature between regions $\mathrm{C}$ and $\mathrm{A}$ because the water masses near the shelf break show some differences between region CB and region $\mathrm{L}$ at $200 \mathrm{~m}$ depth (Fig. 2a, d). The contrasts in the lower ocean appear to be minor (Fig. 2b, c, e, f) and should also be investigated, as discussed in Sect. 5 .

It should be noted that the cyclonic Atlantic Water circulation is dependent on the NAM (Karcher et al. 2012), which shows decadal oscillations. Since the NAM presented positive phases in the early 1970s (Ikeda 2014), the circulation intensified in the mid-1970s. In addition, westerly winds tend to induce onshore Ekman flow and resultant downward flow at the continental shelf break. Thus, the downward flow may have been a rare event that only occurred in the 1970s. The common tendency could have occurred on the reducing water temperature due to downward flow of the cold upper ocean water (Sect. 4.3 in Frolov et al. 2005).

The next question to be addressed is where the lower ocean water masses in region $\mathrm{E}$ come from. Given that the mean $\mathrm{PO}_{4}{ }^{*}$ is $0.78 \mu \mathrm{mol} / \mathrm{L}$ in region $\mathrm{E}$, the main component mixes down from the intermediate layer (Fig. 10). However, large standard deviations of $0.3-0.5 \mu \mathrm{mol} / \mathrm{L}$ are seen in Fig. 8d, e, implying that there are other sources too. The inflow from the Greenland Sea through the Fram Strait shows high DO but low $\mathrm{PO}_{4}$ at $2000 \mathrm{~m}$ depth, leading to $\mathrm{PO}_{4}{ }^{*}=0.52 \mu \mathrm{mol} / \mathrm{L}$ (Table 1). The source in the Greenland Sea could still be discerned in region E. We cannot rule out that this lower ocean water flows from region $\mathrm{E}$ into region $\mathrm{A}$, contributing to the decrease in $\mathrm{PO}_{4} *$ in region $\mathrm{A}$, in line with the flow patterns suggested by Timmermans et al. (2005) and Rudels (2012).

A high- $\mathrm{PO}_{4}{ }^{*}$ component in region $\mathrm{E}$ must be identified. One candidate is the shelf water supplied by the cyclonic Atlantic Water circulation, which passes through the Chukchi Sea and sometimes reaches the Greenland side; i.e., the cyclonic circulation was greatly intensified in the 1970s. We should have the concern how this component reached the lower ocean, same as the sinking flows from the Siberian shelf areas to region $\mathrm{C}$ and region $\mathrm{A}$, and is discussed in Sect. 5. In the upper ocean around the Fram Strait, the Atlantic Water flows into region $\mathrm{E}$ and carries $0.69 \mu \mathrm{mol} / \mathrm{L} \mathrm{PO}_{4}{ }^{*}$. In addition, the descent of the Atlantic Water mass from the northern shelf of the Barents Sea supplies $0.60 \mu \mathrm{mol} / \mathrm{L}$ $\mathrm{PO}_{4}{ }^{*}$ to region $\mathrm{E}$ (Arthun et al. 2011). While these sources are generally accepted to exist, they tend to reduce the $\mathrm{PO}_{4}$ * levels in region $\mathrm{E}$.

The lower ocean, a layer $2000 \mathrm{~m}$ thick, has a volume of about $6 \times 10^{15} \mathrm{~m}^{3}$ in the Amerasian Basin. As the volume of region $\mathrm{A}$ is about twice as large as that of region $\mathrm{C}$, the mean $\mathrm{PO}_{4}{ }^{*}$ is $0.69 \mu \mathrm{mol} / \mathrm{L}$ throughout the entire Amerasian Basin. The volume transport of $0.5 \mathrm{~Sv}$ into this domain yields a renewal timescale of 400 years, which is consistent with the isolation timescale estimated with carbon-14 (Timmermans et al. 2005). Those authors suggested that the over-sill flow from the Eurasian Basin has a flux of $0.25 \mathrm{~Sv}$ toward the Amerasian Basin, and is the main source of the lower-ocean water. The level of $\mathrm{PO}_{4}{ }^{*}$ in region $\mathrm{A}$ is $0.58 \mu \mathrm{mol} / \mathrm{L}$ due to inputs from region $\mathrm{E}$ and region $\mathrm{L}$, which has $0.59 \mu \mathrm{mol} / \mathrm{L}$ $\mathrm{PO}_{4} *$ (Table 1). Although region $\mathrm{E}$ contains spatially heterogeneous $\mathrm{PO}_{4}{ }^{*}$, the results indicate that the input from region $\mathrm{E}$ may be around $0.6 \mu \mathrm{mol} / \mathrm{L}$. We assume that the downward flows from regions $\mathrm{CB}$ and $\mathrm{L}$ are 0.05 and $0.20 \mathrm{~Sv}$, respectively, as the total of the three components should be $0.5 \mathrm{~Sv}$. If we also assume that the transport from region A to region $\mathrm{C}$ is $0.10 \mathrm{~Sv}$, the combined $\mathrm{PO}_{4}{ }^{*}$ is $0.89 \mu \mathrm{mol} / \mathrm{L}$ (see Table 1), which is very close to the mean value of $0.90 \mu \mathrm{mol} / \mathrm{L}$ in region $\mathrm{C}$. Thus, the observed $\mathrm{PO}_{4}{ }^{*}$ values allow us to estimate the flow fields into and towards the 
lower ocean of the Amerasian Basin. It would be desirable to measure the downward flows and $\mathrm{PO}_{4}{ }^{*}$ contents to obtain quantitative estimates of the tracer flux balance.

\section{Summary and discussion of possible sources of detailed information}

We now summarize the results of the present study. An analysis of the HAAC dataset confirmed the generally accepted ocean circulation and water sources for the Arctic Basin and further allowed the visualization of some speculative flow fields, such as downward water movement along the continental shelf break. In the upper ocean (above $500 \mathrm{~m}$ depth), Pacific Water containing river water with high levels of $\mathrm{Si}$ and $\mathrm{PO}_{4}$ circulates anticyclonically near the sea surface, while Atlantic Water circulates cyclonically underneath the Pacific Water, replacing it. As a result of remineralization processes, $\mathrm{PO}_{4}$ and $\mathrm{Si}$ show peaks at around $150 \mathrm{~m}$ depth (above the upper halocline), while DO presents high values near the surface and decreases with depth. High values of $\mathrm{PO}_{4}{ }^{*}$ on the Pacific side suggest an input of $\mathrm{PO}_{4}$ from the Pacific Ocean.

In the intermediate layer (500-1500 m depth), the Upper Polar Deep Water moves upward in the Amerasian Basin and then heads back toward the Atlantic Ocean by mixing with the Atlantic Water in the subsurface layer. In the lower ocean (below 1500 m depth), the Nordic Seas Deep Water enters the Eurasian Basin through the Fram Strait and reaches the Canada Basin, staying at around $3500 \mathrm{~m}$ depth, as shown by the $\mathrm{PO}_{4}, \mathrm{DO}$, and $\mathrm{PO}_{4} *$ distributions. The characteristic values of $\mathrm{PO}_{4} *$ in the lower ocean suggest that downward inputs occur from the continental shelves (i.e., low- $\mathrm{PO}_{4}{ }^{*}$ water travels from the Barents and Laptev seas into the Eurasian and Makarov basins, while high- $\mathrm{PO}_{4}{ }^{*}$ water shifts from the Chukchi and Beaufort seas into the southern Canada Basin). In all cases, the downward flows pass underneath the cyclonic circulation of the Atlantic Water and along the continental slopes from the Fram Strait to the Beaufort Sea. When there is an extremely intense polar vortex, the high$\mathrm{PO}_{4}$ * core reaches the Greenland side and appears in the lower ocean of the Eurasian Basin.

The HAAC dataset does not provide any information on physical properties. The geochemical data in the HAAC dataset were obtained through traditional sampling. More recently, other geochemical parameters have been measured and analyzed too, such as isotopes of carbon (C-14) and others. In the discussion below, we consider the possible roles of those other geochemical parameters as well as physical properties in future research and how they should be measured during data collection.
The inflow from the Atlantic Ocean is clearly reflected in the low Si levels at $2000 \mathrm{~m}$ in the Amundsen Basin (Fig. 4c), but this inflow is not reflected in the $\mathrm{PO}_{4}$ data (Fig. 6c). It is difficult to explain this difference in the distribution patterns between $\mathrm{Si}$ and $\mathrm{PO}_{4}$. It may be attributable to the smaller dataset of $\mathrm{PO}_{4}$ compared with that of $\mathrm{Si}$, or a difference in ocean dynamics may be responsible. We can identify a downward flow containing $\mathrm{PO}_{4}$ from the Barents Sea, which is expected given the high $\mathrm{PO}_{4}$ value observed at $500 \mathrm{~m}$ depth (Fig. 6b). Just as Roeske et al. (2012) used Ba to track freshwater from a specific river, a particular geochemical parameter could be used to track a particular source water.

In the same figures, the distributions at $2000-3000 \mathrm{~m}$ show horizontal heterogeneity off the Beaufort Sea shelf area: i.e., the high- $\mathrm{PO}_{4}$ area occupies only the southern half of the Canada Basin. It is meaningful to question why regions $\mathrm{C}$ and $\mathrm{A}$ are similar in terms of salinity and temperature, whereas there are some differences between region $\mathrm{CB}$ and region $\mathrm{L}$ in their source water masses. We should also track high- $\mathrm{PO}_{4}{ }^{*}$ water masses from the Greenland side towards region $\mathrm{E}$. The sinking water masses need to reach a certain water density level below the halocline. When they reach the sea floor, they must go underneath the Atlantic Water flow along the shelf break. If the dense water produced over the continental shelves plays an important role, it may be necessary to monitor chemical tracers on the isopycnal and diapycnal surfaces. Since the downslope flow is intermittent, we could track how correlations among chemical components and physical parameters depend on density or mixed-layer depth. Unfortunately, the HAAC dataset does not include information on density in situ, so it is impossible to determine the isopycnal surfaces. However, we intend to use the recently collected data on C-14 and CFCs in the Arctic Ocean to attempt this type of study in the Arctic Ocean.

The DO levels in the lower ocean are generally lower on the Pacific side than on the Atlantic side, although the difference between the sides in phosphate content is minimal. In Sect. 4, this contrast is attributed to the descent of the shelf water along the continental slope off the Chukchi and Barents seas. Another possible mechanism was suggested by Devol et al. (1997). Denitrification takes place in the benthic sediment along the continental shelf on the Pacific side, leading to DO depletion. The denitrification results from the decomposition of the large amount of organic matter generated due to the high productivity at the sea surface on the continental shelf. This decomposition utilizes oxygen from the nitrate in sediment pore water trapped between grains, which in turn reduces the DO levels in the benthic deep water. This process does not, however, influence the content of $\mathrm{PO}_{4}$ in the benthic deep water. In order to clarify the processes described above, it is necessary to collect nitrate data for both the benthic water and the sediment pore water along the continental shelf on the Pacific side. 
Acknowledgements Financial support from the Japanese Ministry of Education, Culture, Sport, Science and Technology was fundamental to this work. The authors also greatly appreciate fruitful discussions with Dr. M. Yamamoto-Kawai on the recent geochemical status of the Arctic Ocean, and with Dr. S. Nishino on the general characteristics of the HAAC dataset. In addition, Dr. J. Ono provided recent information on modeling and observations of ocean circulation in the Arctic Ocean. Dr. T. Ikeda provided useful insights into the statistical analysis, and checked the English grammar and phrasing in the manuscript. This study would not have been completed without their support.

Open Access This article is distributed under the terms of the Creative Commons Attribution 4.0 International License (http://creativeco mmons.org/licenses/by/4.0/), which permits unrestricted use, distribution, and reproduction in any medium, provided you give appropriate credit to the original author(s) and the source, provide a link to the Creative Commons license, and indicate if changes were made.

\section{Appendix}

Here, we discuss the statistical methods that we used to analyze the conserved parameter $\mathrm{PO}_{4}{ }^{*}$, as calculated via Eq. 1 .

Three regions are specified. Region $\mathrm{C}$ is the Canada Basin between $150^{\circ} \mathrm{W}$ and $120^{\circ} \mathrm{W}$ and south of $80^{\circ} \mathrm{N}$. Region $\mathrm{A}$ is the Amerasian Basin excluding region $\mathrm{C}$, and region $\mathrm{E}$ is the Eurasian Basin. The lower ocean is divided into two layers: layer 2 corresponds to depths from 2000 to $2999 \mathrm{~m}$, and layer 3 to depths from $3000 \mathrm{~m}$ to the bottom. It should be noted that there are far more data points in each layer of each region than at each depth in Figs. 9 and 10.

Welch's $t$ test is employed as one of the statistical methods. In this test, the mean of all data values, $X_{i}$, and the standard deviation, $S$, are determined as

$\bar{X}=\sum_{i=1}^{N} X_{i} / N$

$S^{2}=\sum_{i=1}^{N}\left(X_{i}-\bar{X}\right)^{2} /(N-1)$

where $N$ is the number of data points. The standard error, $\varepsilon$, is given by

$\varepsilon^{2}=S^{2} / N$.

It should be noted that the standard errors are much smaller than those shown in Figs. 9 and 10 because many more data points are included in the calculation of each mean value.

To determine if the difference between the mean values for two groups of data, G1 and G2, is significant, we determined the standard error, $\varepsilon_{\mathrm{G} 12}$, of the difference between the two mean values as

$\varepsilon_{\mathrm{G} 12}^{2}=\varepsilon_{\mathrm{G} 1}^{2}+\varepsilon_{\mathrm{G} 2}^{2}$, where the subscripts $\mathrm{G} 1$ and $\mathrm{G} 2$ refer to groups $\mathrm{G} 1$ and $\mathrm{G} 2$, respectively. The number of degrees of freedom, $d f$, is calculated as

$d f=\frac{\varepsilon_{\mathrm{G} 12}^{4}}{\varepsilon_{\mathrm{G} 1}^{4} /\left(N_{\mathrm{G} 1}-1\right)+\varepsilon_{\mathrm{G} 2}^{4} /\left(N_{\mathrm{G} 2}-1\right)}$

to adjust for unequal sample sizes and variance. The $t$ value is determined from $d f$ assuming a significance level of $95 \%$. If $\varepsilon_{\mathrm{G} 12}$ multiplied by $t$ is smaller than the difference between the two mean values, the means are adjudged to be significantly different from each other.

The two-tailed Welch's $t$ test shown above assumes a normal distribution of data values. However, this assumption is often not correct, in which case a different method must be used. In the Mann-Whitney $U$ test, which is the nonparametric version of the $t$ test, the data values are ordered from the highest to the lowest to facilitate a comparison between the data distributions of the two groups. The following website was used to calculate the level of significance: http://www. socscistatistics.com/tests/mannwhitney/Default2.aspx.

\section{Results of the statistical analysis}

Differences between region $C$ and region $A$

Layer 3:

$N_{\mathrm{C}}=8$, the mean $=0.9529, S_{\mathrm{C}}=0.1232, \varepsilon_{\mathrm{C}}=0.04358$

$N_{\mathrm{A}}=15$, the mean $=0.5687, S_{\mathrm{A}}=0.1269, \varepsilon_{\mathrm{A}}=0.03277$

$d f_{\mathrm{CA}}=14.7, t$ value $(95 \%$ significance $)=2.14$, the mean difference $=0.3841, \varepsilon_{\mathrm{CA}}=0.05452$

Significant because $0.3841>0.05452 \times 2.14$

Using $U$ test, $Z$ score $=-3.84071, p<0.001$, significant at $95 \%$

Layer 2:

$N_{\mathrm{C}}=15$, the mean $=0.8737, S_{\mathrm{C}}=0.1239, \varepsilon_{\mathrm{C}}=0.03200$

$N_{\mathrm{A}}=21$, the mean $=0.5908, S_{\mathrm{A}}=0.0936, \varepsilon_{\mathrm{A}}=0.02044$

$d f_{\mathrm{CA}}=24.8, t$ value $(95 \%$ significance $)=2.06$, the mean difference $=0.2829, \varepsilon_{\mathrm{CA}}=0.03797$

Significant because $0.2829>0.03797 \times 2.06$

Using $U$ test, $Z$ score $=-4.68476, p<0.00001$, significant at $95 \%$

\section{Differences between region $E$ and region $A$}

Layer 3:

$N_{\mathrm{E}}=21$, the mean $=0.8525, S_{\mathrm{E}}=0.4737, \varepsilon_{\mathrm{E}}=0.1033$

$N_{\mathrm{A}}=15$, the mean $=0.5687, S_{\mathrm{A}}=0.1269, \varepsilon_{\mathrm{A}}=0.03277$

$d f_{\mathrm{EA}}=23.7, t$ value $(95 \%$ significance $)=2.06$, the mean

difference $=0.2838, \varepsilon_{\mathrm{EA}}=0.1084$

Significant because $0.2838>0.1084 \times 2.06$

Using $U$ test, $Z$ score $=2.91995, p<0.005$, significant at 95\%

Layer 2:

$N_{\mathrm{E}}=36$, the mean $=0.7311, S_{\mathrm{E}}=0.3088, \varepsilon_{\mathrm{E}}=0.05146$ 
$N_{\mathrm{A}}=21$, the mean $=0.5908, S_{\mathrm{A}}=0.0936, \varepsilon_{\mathrm{A}}=0.02044$

$d f_{\mathrm{EA}}=45.1, t$ value $(95 \%$ significance $)=2.02$, the mean

difference $=0.1404, \varepsilon_{\mathrm{EA}}=0.05537$

Significant because $0.1404>0.05537 \times 2.02$

Using $U$ test, $Z$ score $=2.27467, p<0.025$, significant at $95 \%$

\section{References}

Aagaard K, Carmack EC (1989) The role of sea ice and other fresh water in the Arctic circulation. J Geophys Res 94:14485-14498

Aagaard K, Swift JH, Carmack EC (1985) Thermohaline circulation in the Arctic Mediterranean Seas. J Geophys Res 90:4833-4846

Aksenov Y, Ivanov VV, Nurser AJG, Bacon S, Polyakov IV, Coward AC, Naveira-Garabato AC, Beszczynska-Moeller A (2011) The Arctic circumpolar boundary current. J Geophys Res 116:C09017. https://doi.org/10.1029/2010JC006637

Anderson LG, Jones EP, Koltermann KP, Schlosser P, Swift JH, Wallace DWR (1989) The first oceanographic section across the Nansen Basin in the Arctic ocean. Deep Sea Res 36:475-482

Anderson LG, Bjork G, Holby O, Jones EP, Kattner G, Koltermann KP, Liljeblad B, Lindegren R, Rudels B, Swift JH (1994) Water masses and circulation in the Eurasian Basin: results from the Oden 91 expedition. J Geophys Res 99:3273-3283

Arctic and Antarctic Research Institute (2001) Hydrochemical atlas of the Arctic Ocean. Arctic and Antarctic Research Institute/ International Arctic Research Center, University of Alaska, St. Petersburg/Fairbanks

Arthun M, Ingvaldsen RB, Smedsrud LH, Schrum C (2011) Dense water formation and circulation in the Barents Sea. Deep Sea Res I 58:801-817. https://doi.org/10.1016/j.dsr.2011.06.001

Bauch D, Rutgers M, Loeff VD, Andersen N, Torres-Valdes S, Bakker K, Abrahamsen EP (2011) Origin of freshwater and polynya water in the Arctic Ocean halocline in summer 2007. Prog Oceanogr 91:482-496. https://doi.org/10.1016/j.pocean.2011.07.017

Broecker WS (1991) The great ocean conveyor. Oceanography 4:79-89

Brown KA, McLaughlin F, Tortell PD, Yamamoto-Kawai M, Francois $R$ (2016) Sources of dissolved inorganic carbon to the Canada Basin halocline: a multitracer study. J Geophys Res Oceans 121:2918-2936. https://doi.org/10.1002/2015JC011535

Codispotia LA, Kelly V, Thessen A, Matrai P, Suttles S, Hill V, Steele M, Light B (2013) Synthesis of primary production in the Arctic Ocean: III. Nitrate and phosphate based estimates of net community production. Prog Oceanogr 110:126-150. https://doi. org/10.1016/j.pocean.2012.11.006

Devol AH, Codispoti LA, Christensen JP (1997) Summer and winter denitrification rates in western Arctic shelf sediments. Cont Shelf Res 17:1029-1050

Ekwurzel B, Schlosser P, Mortlock RA, Fairbanks RG (2001) River runoff, sea ice meltwater, and Pacific water distribution and mean residence times in the Arctic Ocean. J Geophys Res 106:9075-9092

Falkner KK, Steele M, Woodgate RA, Swift JH, Aagaard K, Morison J (2005) Dissolved oxygen extrema in the Arctic Ocean halocline from the North Pole to the Lincoln Sea. Deep Sea Res 52:1138-1154

Frolov IE, Gudkovich ZM, Radionov VF, Shirochkov AV, Timokhov LA (2005) The Arctic Basin; results from the Russian drifting stations. Springer/Praxis, Chichester

Garcia HE, Gordon LI (1994) Oxygen solubility in seawater: better fitting equations. Limnol Oceanogr 37:1307-1312
Haller M, Brümmer B, Müller G (2014) Atmosphere-ice forcing in the transpolar drift stream: results from the DAMOCLES icebuoy campaigns 2007-2009. Cryosphere 8:275-288. https://doi. org/10.5194/tc-8-275-2014

Ikeda M (2014) An ice-ocean model study to explore climate change mechanisms in comparison with interannual-to-decadal variability of geochemical tracers. Adv Polar Sci 25:269-282. https://doi. org/10.13679/j.advps.2014.4.00269

Ikeda M, Colony R, Yamaguchi H, Ikeda T (2005) Decadal variability in the Arctic Ocean shown in hydrochemical data. Geophys Res Lett 32:L21605. https://doi.org/10.1029/2005GL023908

Jones EP (2001) Circulation in the Arctic Ocean. Polar Res 20:139-146

Jones EP, Rudels B, Anderson LG (1995) Deep waters of the Arctic Ocean: origins and circulation. Deep-Sea Res 42:737-760

Jones EP, Anderson LG, Swift JH (1998) Distribution of Atlantic and Pacific waters in the upper Arctic Ocean: implications for circulation. Geophys Res Lett 25:765-768

Karcher M, Smith JN, Kauker F, Gerdes R, Smethie WM Jr (2012) Recent changes in Arctic Ocean circulation revealed by iodine-129 observations and modeling. J Geophys Res 117:C08007. https://doi.org/10.1029/2011JC007513

Levitus S (ed) (2002) World Ocean Atlas 2001, NOAA Atlas NESDIS 52. U.S. Government Printing Office, Washington, DC

Lien VS, Trofimov AG (2013) Formation of Barents Sea Branch Water in the north-eastern Barents Sea. Polar Res 32:18905. https://doi.org/10.3402/polar.v32i0.18905

Mathis JT, Grebmeier JM, Hansell DA, Hopcroft RR, Kirchman DL, Lee SH, Moran SB, Bates NR, VanLaningham S, Cross JN, Cai W-J (2014) Carbon biogeochemistry of the western Arctic: primary production, carbon export and the controls on ocean acidification. In: Grebmeier JM, Maslowski W (eds) The Pacific Arctic Region, ecosystem status and trends in a rapidly changing environment. Springer, Dordrecht, pp 223-268. https://doi. org/10.1007/978-94-017-8863-2_1

McLaughlin F, Carmack E, Proshutinsky A, Krishfield RA, Guay C, Yamamoto-Kawai M, Jackson JM, Williams B (2011) The rapid response of the Canada Basin to climate forcing: from bellwether to alarm bells. Oceanography 24(3):146-159. https ://doi.org/10.5670/oceanog.2011.66

Mizobata K, Watanabe E, Kimura N (2016) Wintertime variability of the Beaufort gyre in the Arctic Ocean derived from CryoSat-2/ SIRAL observations. J Geophys Res Oceans 121:1685-1699. https://doi.org/10.1002/2015JC011218

Pnyushkov AV, Polyakov IV, Ivanov VV, Kikuchi T (2013) Structure of the Fram Strait branch of the boundary current in the Eurasian Basin of the Arctic Ocean. Polar Sci 7:53-71. https://doi. org/10.1016/j.polar.2013.02.001

Pnyushkov AV, Polyakov IV, Ivanov VV, Aksenov Y, Coward AC, Janout M, Rabe B (2015) Structure and variability of the boundary current in the Eurasian Basin of the Arctic Ocean. Deep Sea Res I 101:80-97. https://doi.org/10.1016/j.dsr.2015.03.001

Roeske T, Bauch D, Rutgers M, Loeff VD, Rabe B (2012) Utility of dissolved barium in distinguishing North American from Eurasian runoff in the Arctic Ocean. Mar Chem 132-133:1-14. https ://doi.org/10.1016/j.marchem.2012.01.007

Rudels B (2012) Arctic Ocean circulation and variability-advection and external forcing encounter constraints and local processes. Ocean Sci 8:261-286. https://doi.org/10.5194/os-8-261-2012

Rudels B, Korhonen M, Schauer U, Pisarev S, Rabe B, Wisotzki A (2015) Circulation and transformation of Atlantic water in the Eurasian Basin and the contribution of the Fram Strait inflow branch to the Arctic Ocean heat budget. Prog Oceanogr 132:128-152. https://doi.org/10.1016/j.pocean.2014.04.003

Smedsrud LH, Esau I, Ingvaldsen RB, Eldevik T, Haugan PM, Li C, Lien VS, Olsen A, Omar AM, Ottera OH, Risebrobakken B, 
Sando AB, Semenov VA, Sorokina SA (2013) The role of the Barents Sea in the Arctic climate system. Rev Geophys 51:415449. https://doi.org/10.1002/rog.20017

Smethie WM Jr, Chipman DW, Swift JH, Koltermann KP (1988) Chlorofluoromethanes in the Arctic Mediterranean sea: evidence for formation of bottom water in the Eurasian Basin and deep-water exchange through Fram Strait. Deep Sea Res 35:347-369

Smethie WM Jr, Schlosser P, Bönisch G (2000) Renewal and circulation of intermediate waters in the Amerasian Basin observed on the SCICEX 96 cruise. J Geophys Res 105:1105-1121

Spall MA (2013) On the circulation of Atlantic Water in the Arctic Ocean. J Phys Oceanogr 43:2352-2371. https://doi.org/10.1175/ JPO-D-13-079.1

Timmermans ML, Winsor P, Whitehead JA (2005) Deep-water flow over the Lomonosov Ridge in the Arctic Ocean. J Phys Oceanogr 35:1489-1493

Toole JM, Timmermans ML, Perovich DK, Krishfield RA, Proshutinsky A, Richter-Menge JA (2010) Influences of the ocean surface mixed layer and thermohaline stratification on Arctic Sea ice in the central Canada Basin. J Geophys Res 115:C10018. https://doi. org/10.1029/2009JC005660

Tremblay J-E, Simpson K, Martin J, Miller L, Gratton Y, Barber D, Price NM (2008) Vertical stability and the annual dynamics of nutrients and chlorophyll fluorescence in the coastal, southeast Beaufort Sea. J Geophys Res 113:C07S90. https://doi. org/10.1029/2007jc004547

Wilson C, Wallace DWR (1990) Using the nutrient ratio NO/PO as a tracer of continental shelf waters in the central Arctic Ocean. J Geophys Res 95:22193-22208

Yamamoto-Kawai YM, Tanaka N, Pivovarov S (2005) Freshwater and brine behaviors in the Arctic Ocean deduced from historical data of $\delta^{18} \mathrm{O}$ and alkalinity (1929-2002 A.D.). J Geophys Res 110:C10003. https://doi.org/10.1029/2004JC002793

Yoshizawa E, Shimada K, Ha HK, Kim TW, Kang SH, Chung KH (2015) Delayed responses of the oceanic Beaufort Gyre to winds and sea ice motions: influences on variations of sea ice cover in the Pacific sector of the Arctic Ocean. J Oceanogr 71:187-197. https://doi.org/10.1007/s10872-015-0276-6 